\title{
Trends and Challenges in Irrigation Scheduling in the Semi-Arid Area of Spain
}

\author{
Irene Fernández García ${ }^{1, * \mathbb{D}}$, Sergio Lecina ${ }^{2}$, M. Carmen Ruiz-Sánchez ${ }^{3}{ }^{\mathbb{D}}$, Juan Vera ${ }^{3}$, \\ ${\text { Wenceslao Conejero }{ }^{3} \text { (D), María R. Conesa }{ }^{3} \text { (D), Alfonso Domínguez }}^{4,5}$, José J. Pardo ${ }^{4,5}$, \\ Bruno C. Léllis ${ }^{4,5}$ and Pilar Montesinos ${ }^{6}$ (D) \\ 1 Department of Electric Engineering, University of Córdoba, Campus de Rabanales, 14071 Córdoba, Spain \\ 2 Independent Researcher and Consultant, 50001 Zaragoza, Spain; lecina@iies.es \\ 3 Irrigation Department, Centro de Edafología y Biología Aplicada del Segura (CEBAS-CSIC), P.O. Box 164, \\ 30100 Murcia, Spain; mcruiz@cebas.csic.es (M.C.R.-S.); jvera@cebas.csic.es (J.V.); \\ wenceslao@cebas.csic.es (W.C.); mrconesa@cebas.csic.es (M.R.C.) \\ 4 Universidad de Castilla-La Mancha, Escuela Técnica Superior de Ingenieros Agrónomos y de Montes, \\ Campus Universitario s/n, 02071 Albacete, Spain; Alfonso.Dominguez@uclm.es (A.D.); \\ josejesus.pardo@uclm.es (J.J.P.); brunolellismaria@yahoo.com.br (B.C.L.) \\ 5 Centro Regional de Estudios del Agua (CREA), Campus Universitario s/n, 02071 Albacete, Spain \\ 6 Department of Agronomy, University of Córdoba, Campus de Rabanales, 14071 Córdoba, Spain; \\ pmontesinos@uco.es \\ * Correspondence: g52fegai@uco.es
}

Received: 24 January 2020; Accepted: 6 March 2020; Published: 12 March 2020

\begin{abstract}
A growing international human population and rising living standards are increasing the demand for agricultural products. Under higher pressure over natural resources, environmental concerns are increasing as well, challenging current water use decision-making processes in irrigated agriculture. Higher agricultural productivity means water should be applied more efficiently, which requires instant information on weather, soil, and plant conditions throughout the growing season. An information-based irrigation scheduling application tightened to the spatiotemporal variability of the fields is critical for enhancing the current irrigation system and making better irrigation scheduling decisions. The aim of this study is to review current irrigation scheduling methodologies based on two case studies (woody and field crops) located in semi-arid areas of Southeast Spain. We realize that optimal irrigation programming requires consistent investment in equipment, expenditure on operation and maintenance, and qualified technical and maintenance services. These technological approaches will be worthwhile in farms with low water availability, high profitability, and significant technical-economic capacity.
\end{abstract}

Keywords: water profitability; water scarcity; sensors; big data; information and communication technologies; irrigation scheduling

\section{Introduction}

A growing international population and rising living standards are increasing the demand for agricultural products. At the same time, globalization, markets liberalization, growing pressure on natural resources, and environmental concerns are heightening the need for improved agricultural productivity [1,2].

In the case of irrigated agriculture, meeting this requirement involves a paradigm shift. Maximizing net profits will demand a more economic approach than simply maximizing crop yields. This is significantly complex and challenging, requiring that water be applied in a wiser, more precise, and accurate fashion because the margin for error narrows [3]. 
From an engineering standpoint, achieving the above depends on having more information, using enhanced irrigation systems and making better irrigation scheduling decisions. Instant information is required for a thorough understanding of weather, soil, and plant conditions throughout the growing season. Enhanced irrigation systems are needed for a uniform application of water depths tailored to the spatiotemporal variability of the fields. Better decisions are necessary to convert these capacities into profits.

The scientific community and industry work to meet these needs, taking advantage of geolocated and internet-enabled devices. As a result, a wide range of technologies has been developed. Multiple sensors for weather, soil and plant measurements can supply data continuously and automatically in fixed points located within the field. Weather conditions, soil moisture and temperature, plant sap flow, trunk diameter, and leaf turgor pressure are some of the variables monitored by these sensors [4,5].

Data can also be obtained for the whole field area. Remote and proximal sensing based on radar and spectral sensors onboard satellites, unmanned aerial vehicles, tractors and even centre-pivots and linear-moving irrigation systems allow high spatial and/or temporal resolution monitoring of soil moisture and plant water and nutrient status. Proximal electromagnetic induction sensors can also be used for mapping soil properties along with soil sampling and testing [6-8].

High quality equipment for water application has also been developed. If adequately selected and dimensioned modern irrigation systems can provide excellent performance under a wide range of environmental conditions. Furthermore, variable rate technology enables the application of site-specific water depths according to the spatial variability of the soil and plant conditions throughout the field [8].

Dealing with all these data and irrigation system capabilities involves great analytical complexity. Automated irrigation controllers have been designed for this purpose. These controllers include a module that computes an optimized irrigation scheduling (and a prescription map in the case of variable rate systems) according to a predefined irrigation strategy and goal. The optimization process is based on sensor data or/and output data from simulation models. Given the complexity of the soil-plant-atmosphere continuum and the uncertainty of the available data, artificial intelligence techniques are used to search for the optimal solution. These techniques are also applied in other related processes, such as model calibration and weather and water demand forecasting $[4,8,9]$.

Despite the sophistication of this cutting-edge hardware and software, their prices have become affordable for commercial use. Recent advances in sensors and information and communication technologies have slashed the cost of generating, transmitting, storing and processing large amounts of data. Consequently, the implementation of these technologies in commercial farms is considered feasible, in practice, for improving their economic and environmental footprint. Likewise, its use could improve the adaptation to climate change and to changing water demand and supply patterns, enhancing food security [10-13].

As a consequence, these technologies for irrigation and agriculture are generally being considered by governments and international organizations as promising tools to achieve a sustainable intensification of agricultural production [14-16]. However, some studies carried out in industrialized countries conclude that their adoption is not widespread, and, on average, their economic profitability is low $[17,18]$.

Farmers readily adopt technologies, such as auto-steer machinery and irrigation pivots, which require limited new training and skills. However, adoption of information-intensive technologies, such as soil or plant moisture sensors and related software, is often limited. These technologies require further investments in learning and/or hiring external services for data analysis. Changes in management practices are also often needed to accommodate data-driven decisions. Such requirements may even affect the profile of farmers, shifting from that of a land manager, who grows crops according to his/her practical experience, to farm technician, whose work should also be based on technical knowledge [18-20].

Farmers can adopt very different information technology levels to fine-tune their management practices. Each level encompasses the use of different layers of information. Assessing the value 
given by each information layer is essential for selecting the most suitable technological level for each farm $[5,19,21]$.

The value of information is the increase in the expected value of the outcome arising from the introduction of an additional layer of information in the decision process [22]. It depends on the quality of the data (e.g., precision, trueness and timing), its total cost (e.g., investment, operation and maintenance) and the conditions of the farm (e.g., environmental, agronomic, socio-economic, and technical). Therefore, a particular technology can provide different economic and environmental results depending on the region and farm where it is used $[5,18,21]$.

Selecting and managing the most suitable technological level requires technical knowledge and skills, as well as unbiased information about the performance of the available technologies. Poor information and/or low knowledge and skills mean decisions are made in a context of uncertainty, which in turn, means cultural factors and cognitive biases may lead to the adoption of sub-optimal solutions or simply to no decisions being made. Thus, the early adopters of new technologies are usually younger farmers, with higher education levels and larger farms in terms of economic size [17-19,23,24].

Farms located in the Mediterranean countries of the EU are usually smallholdings managed by aged farmers with a low level of technical education. These features hamper the uptake of new technologies [24]. An example of this situation is Spain, where 59\% of the farmers are older than 55 years and only $18 \%$ have agricultural technical training for the implementation of information and communication technologies (ICTs) on their farms. The mean economic farm size is $37,284 €$ in terms of standard output, which is lower than two thirds of the EU15 average (member states of the EU on 30 April 2004), although the $1 \%$ largest farms ( $\geq 0.5 \mathrm{M} €)$ accounts for $32 \%$ of the national standard output [25].

The Government is tackling this problem by promoting and subsidizing the modernization of irrigation infrastructures. As a result, water transport and distribution facilities, as well as on-farm irrigation systems have been modernized across 1.5 Mha since the beginning of this century [26]. However, a number of studies have suggested that irrigation management should be enhanced in order to capture the full economic and environmental value that modern infrastructure can potentially provide [27-31].

Much research has been specifically conducted to bridge this gap [32-36]. Nevertheless, there are very few analyses focused on identifying the farm conditions that make the techniques developed in these studies profitable. Such analyses, along with a strengthening of extension services, training programs, and regional trials among other measures, would enhance farmers' capabilities to select and use technologies that help them to optimize the management of their irrigation infrastructures $[18,21,24]$.

It is clear from the above overview that carrying out an optimal irrigation scheduling is essential for improving water and energy use in irrigated agriculture. Accordingly, methodologies focused on this issue and advances in new technologies and equipment to be implemented in this sector have been developed. However, in the majority of farms, these advances have not properly got off the ground due to the low technical training of farmers and the reduced profitability of agricultural products, making the investment of new technologies unaffordable. Hence, the aim of this study is to review the main factors influencing irrigation scheduling and document the impact of ICTs on these factors to identify the conditions that drive the return on investment of various irrigation scheduling methodologies. This review is supported by the analysis of several case studies located in semi-arid areas of Southeast Spain, a country with a $30 \%$ of irrigated cropland [37] and most of this area being under Mediterranean natural conditions. The review starts by describing the main factors that should be considered for optimal irrigation scheduling. Then, several case studies methodologies focused on optimal irrigation scheduling applied in both woody and field crops under semi-arid conditions are presented. In the final section, we discuss the strengths and weaknesses of these irrigation scheduling methodologies, based on the case studies evaluated. 


\section{Factors that Affect Optimal Irrigation Scheduling}

Irrigation management depends on several factors, most of which are interrelated, as shown in Figure 1. Different combinations of these factors enable optimal irrigation schedules to be achieved depending on the technological level of the farms (low, intermediate, or high) as regards the technological elements used, as described below.

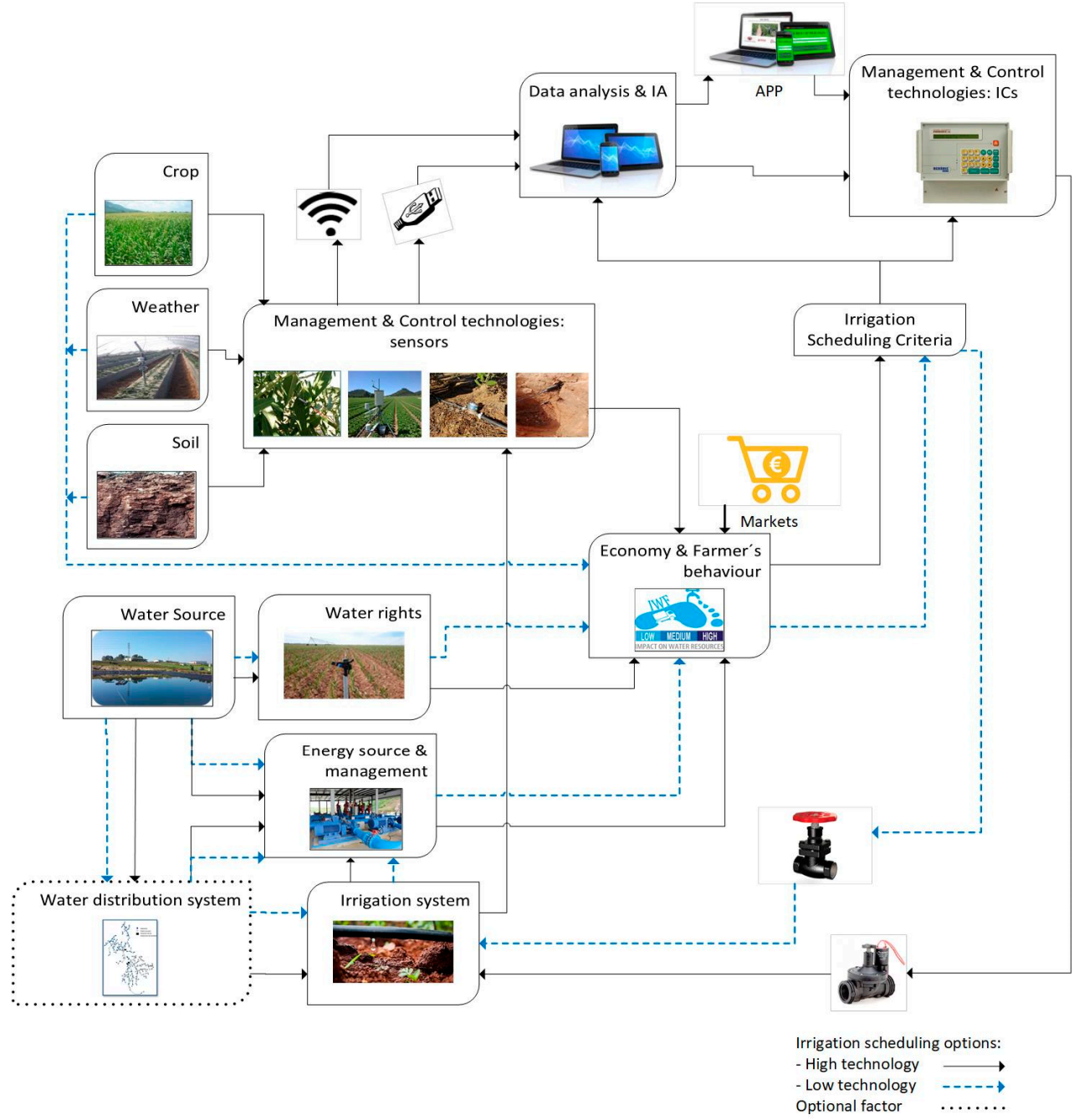

Figure 1. Interaction between irrigation scheduling factors.

- Crop

The crop is the main driver of irrigation scheduling as irrigation is intended to satisfy the fraction of crop water requirements (WR) that cannot be satisfied with rainwater during the crop season. WR are equivalent to the amount of water evapotranspirated by the crop, ETc, which can be linked to the agro-climatic variable, reference evapotranspiration, ETo, by the crop coefficient, Kc [38]. It depends on the crop characteristics, taking into account crop height, the crop-soil surface resistance, and albedo of the crop soil surface [39].

Recommended Kc values for different crops can be found in the literature [38]. However, there are no available $\mathrm{Kc}$ values for certain crops, or the recommended values are suited to different environmental conditions [40]. Thus, different works have focused on setting specific Kc values considering on-site environmental conditions by relating the ETc with ETo using lysimeters [41-44]. Alternatively, other authors have used crop simulation models to determine specific Kc values for non-stressed and well irrigated crops (e.g., bean and cabbage crops in Germany [45]). 
The use of specific crop coefficients can improve irrigation programming, generating both higher yields and water use efficiency [46].

- Weather data

Local weather determines crop irrigation requirements (IR) and consequently irrigation programming.

Rainfall and air temperature are the basic data required to calculate IR using values of effective precipitation (Pe) and ETo estimated by low-parameter procedures like the Hargreaves equation [47]. However, many weather stations can now also record data such as humidity, solar radiation and wind speed, among others (e.g., [48]). When this information is available, physically based ETo calculation methods, such as the Penman-Monteith model [38], can be used to provide accurate estimations of ETo $[49,50]$. Thus, in many cases, there is either a lack of data or their quality is not guaranteed, or the weather station is located too far from the area studied [51,52]. This leads to non-accurate ETo estimations [53] which means uncertainties in the irrigation programming.

- Soil data

Soil characteristics such as soil condition, slope, texture, structure, depth, organic matter content, bulk density, salinity, acidity drainage, fertility and chemical parameters affect soil water distribution and root water absorption [54]. Standard numerical soil properties at a spatial resolution of $250 \mathrm{~m}$ and at a global scale can be obtained from systems such as SoilGrids ${ }^{\mathrm{TM}}$ [55]. However, soil measurements are point measurements that show spatiotemporal variability in the same field during the irrigation season. Accordingly, these authors evaluated the time and spatial variability of soil hydraulic characteristics during the cropping season, showing that soil variations during the season are important and lead to inaccurate irrigation programming. Irrigation events also affect soil hydraulic characteristics, which highlights the importance of carrying out soil hydraulic parameter analysis during the cropping season to improve irrigation programming [56].

In sandy soils, with a low water retention capacity, spatiotemporal hydraulic characterization is crucial $[57,58]$. As an example of watering difficulties in sandy soils, in a two-season study of irrigated potato cultivated in a sandy soil in USA, soil water storage and deep drainage at several zones across the farm were evaluated [57], detecting a significant spatiotemporal variability in soil water storage and temporal differences on deep drainage. To reduce deep drainage, soil water movement models like Hydrus 2-D were used to set the optimum duration of irrigation pulses in strawberries cultivated in extremely sandy soils in Spain, for each crop development stage [58].

- Irrigation scheduling criteria

Irrigation scheduling consists of setting the timing and the amount of water to be applied to the crop [59] to either maximize the production or to maximize the benefit [59]. Over recent decades, these goals have also been linked to efficiency criteria in the use of both water and energy resources [60]. To achieve them, several "irrigation criteria" have been used to establish the irrigation scheduling: (1) A farmer's perception/ experience of crop irrigation needs, which usually results in less-than-optimal irrigation scheduling (lack of water during some crop stages and over-irrigation in others) and hence, lower production and profits [61]; (2) Rational estimation of daily crop irrigation requirements using historical climate data that are daily updated during the irrigation season [62]; (3) Rational estimation of daily crop irrigation requirements based on both climate information and on daily soil water balance [63,64]; (4) Estimation of daily irrigation needs using soil water data collected from soil moisture sensors [65,66]; (5) Irrigation needs estimated from plant water status monitoring using sap flow sensors [5,67], trunk growth rate sensors [68], leaf water potential [69], or leaf turgor pressure sensors [70], among others.

The above criteria define the daily irrigation program once the irrigation strategy is established. Several factors condition the irrigation strategy: the water allocation for the whole season (from full irrigation to different levels of deficit irrigation [71]); the type of irrigation system and its hydraulic characteristics $[62,63]$; or water availability at field scale, according to the management of the irrigation 
district (on demand irrigation in which farmers can irrigate $24 \mathrm{~h}$ a day or by irrigation turns [72,73]), to name a few.

- Water source, water rights, and water markets

Water sources for irrigation include groundwater from wells, surface water, rain harvesting and treated water from municipal areas [74]. The kind and quality of water source affects water availability at field scale. For example, groundwater is a more reliable water source and less vulnerable to drought compared to surface water [75]. As for using rain harvesting pond or treated water for irrigation, water availability will be affected by climatic variables, the pond storage capacity, and the legislation on that issue $[76,77]$.

Water rights are required to legally establish the available water at field scale. "A water right is a legal entitlement authorizing water to be diverted from a specified source and put to beneficial, non-wasteful use" [78]. Hence, water rights affect irrigation programming.

To name a few examples, in England, a license is required to abstract water for irrigation and to obtain/ renew this license, farmers must demonstrate that water is used efficiently [79]. In areas of high competition for water, such as the Mediterranean basin, the water authorities usually impose restrictions on water use that do not always make the producer aware of the efficient use of irrigation water, implementing precision irrigation based on optimal irrigation schedules [80]. In Spain, water allocations are usually assigned per crop, causing occasional disputes between water authorities and farmers, who demand more water [81].

In other areas, water rights are characterized by elements such as priority date, whereby users who first acquired water rights take preference in accessing water resources over other users who obtained their rights later. Hence, during droughts periods, reductions in water allocations affect "new" farmers first [82]. Accordingly, in a study carried out in California's Central Valley on the effects of water rights on agricultural production during drought periods, it was shown that watersheds whose farmers have more senior water rights have on average better agricultural productivity outcomes than watersheds with more junior rights [83].

In some semi-arid countries, particularly during droughts, economic instruments to deal with water allocations are available. Water markets are one such instrument, enabling voluntary water exchanges between users. Australia, and to a lesser extent, Spain and California, are three representative examples of water trade [84]. In a study on the effects of droughts on water markets in the three regions indicated above, the authors highlighted that drought periods are a triggering factor for water trade between users [84].

- Water distribution system and irrigation system.

Open channel water distribution networks usually entail higher water losses than pressurized irrigation networks [85]. Therefore, these losses must be taken into account for irrigation programming [86]. Conversely, pressurized irrigation networks show higher water use efficiency but also increased energy requirements [87]. In these kinds of networks, the operating conditions should be considered in the design of such networks. This ensures that hydrant service conditions are adequate for the proper functioning of on-field irrigation systems, applying the expected water depth and avoiding inadequate irrigation schedules that lead to inefficient use of water [88].

The hydraulic features of the on-farm irrigation system must also be considered to establish the irrigation programming. These features depend on the type of system (surface, sprinkler, or trickle) and its design (layout) and hydrant operation (sectoring) [63,89].

- Energy source and its management

Pressurized water distribution and application systems are generally more efficient in the use of water than open channel systems. For this reason, they have become common in recent decades [90]. 
However, the price to be paid for this improvement is the augmentation of energy costs, in many cases leading to increases of more than $50 \%$ in the cost of irrigation compared to previous gravity irrigation systems [85].

In recent years, numerous studies have aimed to optimize the use of water and energy in irrigation systems at irrigation district scale considering the operation of the network (sectoring, control of critical points or electric tariff selection, [91-93]). The operation of the main hydraulic networks designed to reduce energy costs may limit the available irrigation time for farmers conditioning the irrigation schedule of their fields. For example, some irrigation districts (ID) in Spain have reduced their energy costs by choosing the lowest electric tariff: farmers can irrigate during the night from Monday to Friday and for $24 \mathrm{~h}$ on Saturdays, Sundays, and bank holidays [73]. Their energy costs savings are about $25 \%$ for similar water use [94].

However, optimal management of irrigation networks does not avoid the dependence of irrigation agriculture on fluctuations in energy prices. Therefore, in recent years, the reduction of electricity production costs from renewable energy sources (wind, solar photovoltaic and micro hydropower) is facilitating their incorporation into the irrigation sector $[64,95,96]$. Since the generation of energy depends on suitable weather conditions (sufficient wind or solar radiation for pumping), irrigation must be scheduled around the availability of renewably sourced energy [64].

- Management and control technologies

The technological development of the last decade has had enormous repercussions in irrigation management and control. Today's commercial sensors and irrigation controllers, ICs, provide a good value for money in an affordable price range for most farmers. In addition, the constant improvement of information and communication technologies, ICTs, facilitates the interaction between sensors, IC, and users through web platforms and applications for mobile devices [62,97].

ICs open and close pipes remotely enabling or disabling the electro-valves associated with each irrigation sector according to the irrigation times programmed (input data). These are key devices to make irrigation easier for farmers as they can start and finish irrigation at any time, no matter day or night, during the daily period available for irrigation with daily, weekly or monthly frequency. Input data are introduced by the user, or a baseline irrigation schedule is updated periodically according to real time information on the variables that affect irrigation (e.g., soil moisture, pressure at the pumping station, irradiance) measured by sensors [64]. The IC's operational rules may be simple (exceedance of threshold values) or optimal irrigation schedules based on soil-plant-water models and optimization procedures [34,98-101]. Thus, the IC installed on a farm conditions the irrigation programming.

There currently exists a wide range of commercial sensors to monitor and control crop, soil, climatic variables and the irrigation network. Their records are stored in data loggers that, in most cases, can be remotely accessed by ICs and/or web platforms/app for mobile terminals.

Web platforms funded by either public institutions or private associations to support irrigation programming have become a common tool among technical staff and farmers, many of them accessible by apps for smartphones/tablets, thanks to the exponential development of ICTs in recent years [102]. Irrigation apps allow farmers to visualize the key variables of each event, and even act on the system from almost anywhere, as telecommunication coverage has improved in rural areas. Web platforms and apps are accessible for both individual farmers and irrigators' associations, expanding the number of potential users compared to the supervisory control and acquisition data systems, SCADA, which monitored and controlled systems from a fixed location and were restricted to associations and large farms, but which have been a key factor in the digitization of irrigated agriculture [103].

The spatiotemporal variability of applied water depth should be considered to improve irrigation scheduling. Remote sensing techniques based on the use of satellite images and unmanned aerial vehicles, or geostatistical methods that require either detailed soil study and dense sampling or estimation of soil moisture content from alternative low-cost techniques (e.g., electromagnetic induction exploration techniques) are complementary tools for monitoring the real application of irrigation water. 
This permits the visualization of the spatial variability of soil water content, splitting the cropped area into irrigation sectors with ad hoc irrigation programs $[30,104,105]$.

- Data analysis and artificial intelligence (AI)

The modernization of many irrigation networks involved not only the change of hydraulic infrastructures, but also the installation of telemetry devices, initially aimed at automating billing, recording consumption at user level at certain intervals (big data collection) [103].

The robustness of the current telemetry systems, most of which are based on wireless communication, facilitates database feeding with large amounts of data. It is increasingly common today for farmers' associations to record detailed information on their users' water consumption (hourly consumption) throughout the irrigation campaign. These massive data sets (weather, crop, soil, irrigation network operation and even markets data) require storage space (e.g., cloud storage) to be further processed by AI techniques. There are a wide variety of AI techniques, such as artificial neural networks, fuzzy logic, or decision trees, that can be applied separately or combined to improve the accuracy of irrigation programming $[98,102]$.

Consumption data linked to water use features at hydrant level (soil, critical periods of crop development, water allocation, etc.), agroclimatic information provided by public and/or private web platforms and, when available, the knowledge of farmer's behaviour (related, for example, to their perception of weather conditions, national holidays and vacation periods) allow accurate predictions of irrigation scheduling at farmer scale (when, how much and for how long he/she irrigates) [106-108]. Accurate individual irrigation schedules aggregated at irrigation district level provide valuable information for managers to optimize the use of water and energy.

- Economy and farmer's behaviour

The costs of current irrigation scheduling systems (e.g., ICs, sensors, apps, web platforms, etc.) are generally falling. However, for moderate- to low-profit crops, this technology may still be cost-prohibitive if it doesn't significantly increase farmer income [61]. However, the production of high value crops in areas with low water availability, such as greenhouse crops in Southeast Spain, is highly technological, particularly in irrigation scheduling [109].

Market demands have a great influence on farmers, as the economic factor is the main driver for improving their irrigation management (including technology). Markets, especially for fresh products, demand products be obtained sustainably. Water plays a crucial role in the concept of sustainability applied to irrigated agricultural production. For growers, it is increasingly important that their products are identified as sustainable through the corresponding indicators and certifications, in order to maintain or even increase their market price. For example, the use of the Water Footprint indicator (volume of water used throughout the growing season divided by the production obtained) [110], which can be estimated by applying different methodologies (waterfootprint.org, ISO14046 standard [80,111]), encourages the use of optimal irrigation scheduling systems to make efficient use of water while maintaining production levels.

\section{Actual Cases of Application of Optimal Irrigation Programming}

\subsection{Automatic Irrigation Scheduling in Woody Crops}

This study case focuses on the results obtained in the implementation of an automated irrigation protocol based on water uptake estimated from soil water content data, measured by multi-capacitance probes, on two early-maturing Prunus persica L. orchards growing in semi-arid conditions in Southeast Spain. This area is subject to Mediterranean climate where water resources are dwindling, and agriculture sector accounts for $80 \%$ of all water withdrawals. Under this scenario, most water user associations must deal with permanent water deficits through the irrigation season. The water application for high crop yield and quality must be carried out in such a way as to be efficient in relieving 
stress in the most sensitive phenological phases by applying deficit irrigation (DI) strategies [112]. DI requires the use of sensors for real time monitoring of the soil-plant-atmosphere system [113].

A controlled deficit irrigated peach tree experiment and a full-irrigated nectarine tree experiments are described in the following subsections. Both studies aim to compare irrigation scheduling based on soil water sensors with an ETc-based treatment.

\subsubsection{Experimental Site and Plant Material}

The experiments were carried out at the CEBAS-CSIC experimental field station in Santomera, Murcia, Spain ( $38^{\circ} 06^{\prime} 31^{\prime \prime} \mathrm{N}, 1^{\circ} 02^{\prime} 14^{\prime \prime} \mathrm{W}, 110 \mathrm{~m}$ altitude) in two adjacent early-maturing Prunus persica (L.) Batsch tree orchards: peach trees ( $c v$. Flordastar) were spaced $5 \times 5 \mathrm{~m}$, and nectarine trees (cv. Flariba) $6.5 \mathrm{~m} \times 3.5 \mathrm{~m}$, both trained to an open-centre canopy. The soil in the $0-0.5 \mathrm{~m}$ layer was stony, highly calcareous ( $45 \%$ calcium carbonate), with a clay loam texture (clay fraction: $41 \%$ Illite, $17 \%$ Smectite, and $30 \%$ Paligorskita). The average bulk density was $1.43 \mathrm{~g} \mathrm{~cm}^{-3}$. The soil water content at field capacity and wilting permanent point were 0.29 and $0.14 \mathrm{~m}^{3} \mathrm{~m}^{-3}$, respectively.

The average electrical conductivity $\left(\mathrm{EC}_{25^{\circ} \mathrm{C}}\right)$ of the irrigation water was close to $1.3 \mathrm{dS} \mathrm{m} \mathrm{m}^{-1}$. The irrigation system ( $97 \%$ uniformity coefficient) consisted of a single drip line per tree row with pressure-compensated emitters $\left(8 \times 2 \mathrm{Lh}^{-1}\right.$ and $4 \times 4 \mathrm{Lh}^{-1}$ per tree for peach and nectarine trees, respectively) evenly distributed along the lateral.

Harvesting took place in the first week of May. Other standard cultural practices such as winter pruning (during dormancy), thinning (March) and pest control were performed by experiment station personnel. More details on plant phenology can be found in [114].

Two treatments were considered: a control (conventional $100 \% \mathrm{ET}_{\mathrm{c}}$ as $\mathrm{ET}_{0} \times \mathrm{Kc}_{\mathrm{c}}$ computations, [37], $\mathrm{Kc}$ from [115] and an automated irrigation scheduling based on soil water content values. These were distributed in a completely randomized design with four repetitions per irrigation treatment, each consisting of one row of 13 trees (peach) and six trees (nectarine).

\subsubsection{Measurements}

Agrometeorological data, including air temperature, relative humidity, wind speed, global radiation, precipitation, and $\mathrm{ET}_{0}$ (FAO56-Penman Monteith, [37]) were recorded by an automated weather station located at the CEBAS-CSIC experimental field station and integrated in a web server (http://www.cebas.csic.es/general_spain/est_meteo.html). The climate conditions registered were those typical of Mediterranean areas, characterized by high seasonality summarized as hot and dry summers and cool and wet winters with high evaporative demand ( $\mathrm{ET}_{0}$ ten-year average values of $1320 \mathrm{~mm}$ ) and low rainfall, normally below $250 \mathrm{~mm}$.

The volumetric soil water content (VSWC) was monitored with multi-depth capacitance FDR (Frequency Domain Reflectometry) probes (EnviroSCAN) assembled with a PCB interface SDI-12. Four PVC access tubes were installed $0.1 \mathrm{~m}$ to the emitter located close to the tree trunk in four representative trees, one of each replication. Each capacitance probe had sensors fitted to $0.1,0.3,0.5$ and 0.7 (nectarine), 0.8 (peach) $\mathrm{m}$ depth, and were connected to a radio transmission unit, which read every $5 \mathrm{~min}$ and recorded the average value every $15 \mathrm{~min}$. The sensors were previously normalized on air and irrigation water and, subsequently, converted to VSWC using Sentek's default calibration for a clay-loam soil. Average VSWC values in the $0-0.5 \mathrm{~m}$ soil profile were calculated, since they correspond to the maximum root density area [116]. Volumetric counters were installed for each treatment and drip gauges were placed below the emitter, in the same place location as the capacitance probe, to monitor real time irrigation amount.

Probes were connected to a radio transmission unit network sending data to a gateway connected via $\mathrm{TCP} / \mathrm{IP}$ to an AddVantage web server. In this server, a feedback condition was in charge of triggering and closing electrovalves depending on mean field values. Irrigation alarms were also defined to prevent water losses, and electrovalve failures. 
Tree water status was evaluated weekly from March to October in one mature leaf per tree and replications $(\mathrm{n}=4)$, by measuring midday stem water potential $\left(\Psi_{\text {stem }}, \mathrm{MPa}\right)$ using a pressure chamber (Soil Moisture Equip. Corp. Model 3000). Net $\mathrm{CO}_{2}$ assimilation rate and stomatal conductance were measured along the season with a portable gas exchange system (LI-COR, LI-6400) for validating irrigation practices.

\subsubsection{Automated Irrigation Criteria}

The automated irrigation treatment was based on VSWC values in the $0-0.5 \mathrm{~m}$ depth, thus soil sensors become practical biosensors of the root water uptake. One deeper sensor would monitor the wetting front beyond the roots. Integration of average VSWC values and the threshold values acted on electro-valves by the telemetry system.

As described by $[117,118]$ in the peach orchard, the first approach consisted of monitoring the VSWC pattern in the peach orchard throughout the season using conventional ETC values for irrigation. This resulted in over- and under-irrigation, indicating that better scheduling was needed. In the second approach, irrigation was automatically managed by checking the VSWC at 22:00 h, and irrigation only started if the SWC in the top 0.5 m layer at this time was below $95 \%$ of field capacity (FC) and stopped when the sensor at $0.8 \mathrm{~m}$ depth showed an increase of $2 \%$ over its value recorded at 22:00 $\mathrm{h}$. This procedure induced a "divergent pattern" on VSWC with a progressive decrease in VSWC at $0.8 \mathrm{~m}$, with increasingly higher levels needed before reaching the target.

In the third approach, real-time irrigation was managed according to different VSWC threshold values, as proposed by $[119,120]$, based on the different sensitivities to water stress depending on the phenological stage of the tree [121], with two periods: during fruit growth, when irrigation started at 95\% FC and ended at FC, and during post-harvest, when irrigation started at 90 and ended at $95 \% \mathrm{FC}$. Subsequently, the post-harvest period was divided into two: early (mid-May to mid-July, with 90 and $95 \%$ FC, for start and end of irrigation, respectively) and late (from mid-July onwards, with 85 and $90 \%$ FC, respectively).

The fourth approach consisted of converting previous trigger/stopping criteria into the universal management allowed depletion (MAD) fraction, derived from the original water availability concept [122]. For stone fruit tress under drip irrigation, the values $\alpha=0.1$ MAD during the critical period (fruit growth and early postharvest) and $\alpha=0.3$ MAD during late-postharvest were applied (Figure 2). This approach was studied in a nectarine orchard (with a similar phenology calendar as in peach) with the aim of fulfilling plant water requirements [123].

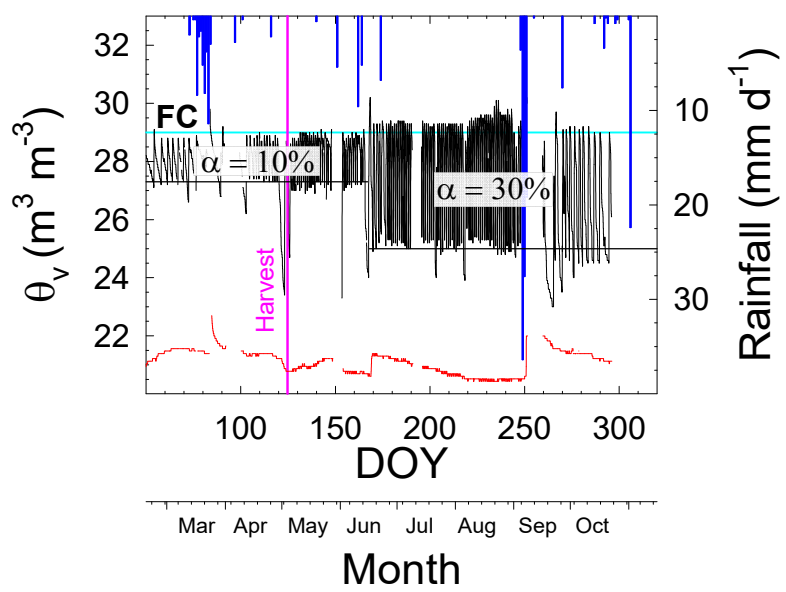

Figure 2. Average volumetric soil water content (VSWC, $\theta_{\mathrm{v}}$ ) values in the $0-0.5 \mathrm{~m}$ soil profile (black line) and at $0.7 \mathrm{~m}$ depth (red line) during the 2015 irrigation season in the nectarine orchard. Blue horizontal line corresponds to field capacity (FC) and black lines correspond to the management allowed depletion $(\mathrm{MAD}, \alpha)$ imposed threshold values. Vertical blue bars indicate daily rainfall. 


\subsubsection{Results}

The mean VSWC values recorded during the studied periods, in both peach and nectarine experiments, varied between the imposed threshold values, for automatically start and stop irrigation, demonstrating the suitability of the automated irrigation strategy. It should be noted that irrigation events could occur at any time of the day according to the rules defined above, and when precipitation events matched with irrigation, irrigation was automatically stopped as soon as VSWC reached the imposed values. It must be pointed out that only heavy precipitation events, such as those recorded during spring (46.6 $\mathrm{mm}$ in March and $87 \mathrm{~mm}$ early September) (Figure 2), induced significant increases in VSWC values at $0.7 \mathrm{~m}$ depth, possibly causing some water losses through the plant root influence. However, VSWC at a deeper soil profile remained constant most of the time. Therefore, drainage can be assumed to be negligible under these conditions.

VSWC-based treatment induced moderate water deficits in peach trees as indicated the lower $\Psi_{\text {stem }}$ values (up to $-1.5 \mathrm{MPa}$ ) compared with the control trees (around $-0.8 \mathrm{MPa}$ ) during the postharvest period $[117,120] . \Psi_{\text {stem }}$ values for nectarine trees remained around $-1 \mathrm{MPa}$ in both treatments [123].

As many authors have proposed for deciduous fruit trees [117,121,124-126], the post-harvest period is suitable for applying regulated deficit irrigation strategies because this stage is less sensitive to soil water deficits than during fruiting. Interestingly, in the two studied early-maturing Prunus cultivars, post-harvest is the longest period of the growing season, accounting for $80 \%$ of the water requirements needed for the entire irrigation season [120], and is important because it is when carbohydrate reserves are accumulated and the floral differentiation process occurs [127]. Accordingly, water deficits should be managed carefully in order to avoid severe plant water deficits that would reduce bloom and fruit load in the next season's harvest [117,120,121,125,126,128].

Other studies have indicated that monitoring the VSWC with capacitive FDR probes improved overall irrigation, providing good calibration, installation, and data acquisition and interpretation [113,114,120,129].

Ref. [130] suggested pulsed irrigations based on MAD (maintained between 50 and 15\%) for automated irrigation of watermelons; when the given set point was detected, a $30 \mathrm{~min}$ irrigation cycle was initiated followed by a $1 \mathrm{~h}$ wait period. Furthermore, [131] compared several irrigation scheduling algorithms including, among others, soil-based ones using granular matrix sensors and soil water balance. They concluded that the latter seemed to be economical, easy to implement and accurate for automatic irrigation management of drip-irrigated apple trees.

Our findings indicated that irrigation scheduling based on precise VSWC threshold values is a useful tool for monitoring the soil water status, allowing automatic and efficient irrigation management. When probes are located at the maximum root exploration volume and the thresholds were precisely defined, an adequate plant water status was favoured, resulting in slight water deficits limiting only vegetative growth while maintaining high yields with prime quality. A peach yield of $18.2 \mathrm{tha} \mathrm{h}^{-1}$ was obtained in the soil-based treatment, which was non-significantly different in comparison with $20.1 \mathrm{tha}^{-1}$ in the traditional scheduled trees, allowing a 33\% of water saving against an irrigation application of 7000-7300 $\mathrm{m}^{3} \mathrm{ha}^{-1}$ ) [117,120].

In addition, the real-time SWC values led to the automation of irrigation without inducing water stress in nectarine trees, deriving irrigation factors that in a practical, easy and precise manner, allowed precision irrigationto be managed [123]. Annual water requirements for early-maturing nectarine trees, in the agro-climatic area of Region de Murcia (Southeast Spain), figured $\approx 6600 \mathrm{~m}^{3} \mathrm{ha}^{-1}$, with irrigation frequency varying from $<1$ to 7 days a week depending on the phenological period. However, in this experiment only $4500 \mathrm{~m}^{3} \mathrm{ha}^{-1}$ were applied, with around $30 \%$ of water savings as compared to control trees irrigated following traditional FAO-56 approach.

\subsection{Irrigation Scheduling in Arable Crops}

Agriculture in Castilla-La Mancha (CLM) occupies an area of 3,773,029 ha, of which 557,851 ha are irrigated lands [132], mainly with sprinkler and drip irrigation systems. The use of irrigation in the area is the result of low average annual precipitation (around $400 \mathrm{~mm} \mathrm{year}^{-1}$ ) and high reference 
evapotranspiration ( $\left.>1100 \mathrm{~mm}_{\text {year }}{ }^{-1}\right)$, characterizing the area as semi-arid [133]. The most common irrigated crops are grapes, cereals, garlic, onion, melon, watermelon, pepper, and others such as sunflower, potato, and alfalfa.

Approximately $70 \%$ of the irrigable area in CLM is located close to groundwater sources (average electrical conductivity EC $=0.8 \mathrm{dS} \mathrm{m}^{-1}$, which is suitable for irrigation), given that most surface water resources are used in other bordering regions. In order to avoid the overexploitation of these aquifers, farmers are restricted in the use of water by the water authority in the area "Confederación Hidrográfica del Júcar" in the case of the Eastern Mancha aquifer, and "Confederación Hidrográfica del Guadiana" in the case of the Western Mancha and Campo de Montiel aquifers). Every year, the water authority determines the amount of water that each farmer can use, depending on the progression of the piezometric levels of the aquifers. Consequently, the total area irrigated in the region varies each year, as does the crop pattern, which is conditioned by the evolution of the harvest prices. Moreover, the increasing cost of energy required for pumping groundwater and irrigating crops using pressurized irrigation systems is another factor conditioning the use of water and the profitability of the irrigated farms. Groundwater in the area is free, but farmers must pay for the energy and the amortization of the irrigation systems. Thus, the average water cost in the area is around $0.12 € \mathrm{~m}^{-3}$ [134].

Large areas of rainfed land were transformed into irrigated land during the 1970s and 1980s, whereby the average size of the holdings (rainfed and irrigated) is about $33 \mathrm{ha}$, which is an appropriate size for farm profitability. However, only $8 \%$ of farmers are younger than 40 years, and many of them combine agriculture with other activities, fostering the adoption of innovative methodologies and the modernization of their exploitations [135].

As a way to maximize the production profitability of irrigated crops in water scare regions such as CLM, the Regional Centre of Water Research (CREA) of Castilla-La Mancha University (UCLM) has developed MOPECO (economic optimization model of irrigation water) [136-138]. The model is based on FAO-33 [139] and FAO-56 [38] methodologies, and has been calibrated for different annual extensive crops in several areas of the world [137,140-145]. MOPECO is designed to provide farmers with a reliable and friendly on-line tool for the proper management of farms and crops based on water productivity (WP).

\subsubsection{Optimal Distribution of Crops and Optimized Irrigation Scheduling}

MOPECO's main goal is to maximize the gross margin (GM) of irrigable lands dedicated to the cultivation of annual crops through the efficient use of irrigation water and available irrigable area. A set of data (Figure 3) is required for the simulation of the optimal "Yield vs. Total Net Water" (Y vs. TWN), function of each crop under the climatic conditions of a certain year being TWN = net irrigation (IN) + effective rainfall (Pe). To obtain Y vs. TWN, the model simulates a range of deficit irrigation schedules using the optimized regulated deficit irrigation (ORDI) methodology [137], considering the effects of irrigation uniformity [146] and electrical conductivity of water on yield [141].

The ORDI methodology maximizes crop yield for a certain actual evapotranspiration value (ETa) versus maximum evapotranspiration rate (ETm) objective for the whole crop growing period. The methodology determines the value of the ETa/ETm ratio for the main Ky (crop yield response factor by growing stage; [139]) stages defined for each crop (i.e., establishment and vegetative development, flowering, grain development and ripening in the case of cereals). This combination of ETa/ETm rates maximizes the crop yield according to the simulations carried out, using the equation proposed by [147]. Consequently, this methodology allows the Y vs. TWN function to be generated by simulating several irrigation schedules (the model determines 100 points of the function, but the user may vary this number). 

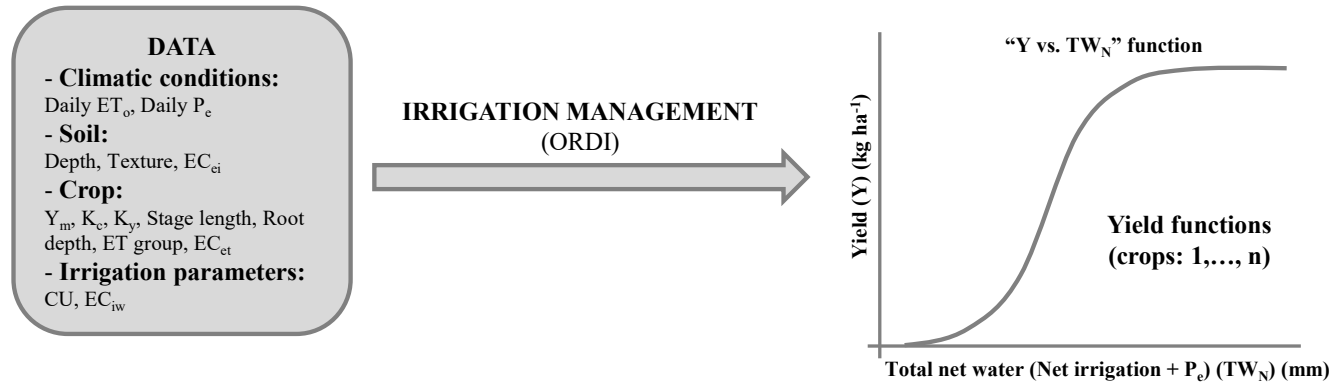

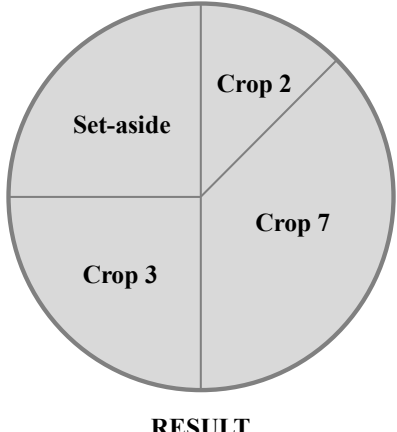

Distribution of crops (in terms of area and volume for irrigation) that maximizes gross margin under the climatic conditions of year $x$
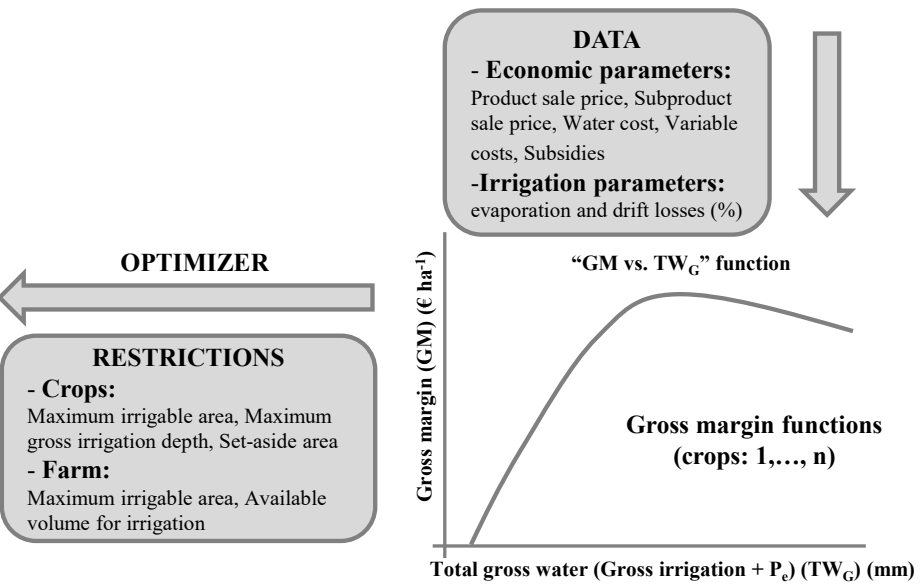

Figure 3. MOPECO flowchart.

In order to decrease the number of simulations for determining the crop irrigation requirements under local climatic conditions, the typical meteorological year (TMY) [148] was adapted by [144] for irrigation scheduling. A TMY consists of 12 months selected from individual years and concatenated to form a complete year with daily unmodified values (maximum and minimum temperature, ETo and rainfall) which show a perfect interrelationship. In order to consider several scenarios of irrigation water requirements, dry, intermediate, and wet TMYs were considered [145].

The Y vs. TWN function is translated into "Yield vs. Total Gross Water" (Y vs. TWG), where TWG = gross irrigation $(\mathrm{IG})+\mathrm{Pe}$, to include the application efficiency of the irrigation system. The Gross Margin (GM) vs. TWG function is then calculated using crop economic data. Finally, the model calculates the optimal crop distribution and the amount of water assigned to each crop that fulfils the restrictions imposed by the user (selected crops, total irrigable area, and total available volume of irrigation water) for certain climatic conditions through the direct solution algorithm developed by [136]. This algorithm calculates the reference points where the tangent lines that connect each pair of GM vs. TWG functions show the maximum slope. These tangent lines define the "Pareto front" [149], which represents the maximum GM possible for each irrigation depth supplied to the crop. On this line, it is impossible to benefit one variable affecting the GM without damaging another.

Therefore, MOPECO uses historic economic and climatic data to provide farmers the most likely crop distribution to maximize the profitability of their farms (Figure 3).

In the optimal crop distribution, MOPECO usually assigns a volume of water to crops lower than their full irrigation requirements for the climatic conditions of the typical meteorological year (TMY) $[144,148]$. This is because maximum GM is generally reached by applying irrigation depths lower than that required for the maximum yield (Figure 3) due to the effect of irrigation uniformity, water cost, and water crop productivity (WP), which usually increases with deficit irrigation [150]. Moreover, under real conditions, future climatic data are unknown, and it is consequently impossible to determine the optimal irrigation schedule at the beginning of the irrigation season.

To solve this question, [138] developed ORDI for limited volumes of irrigation water, which modifies the ETa/ETm objective of the different Ky stages in several consecutive optimizations, 
according to the progression of the real climatic conditions, the amount of irrigation water applied at the end of each stage, and the volume available for the following ones. In order to maximize yield, the methodology determines the deficit in terms of ETa/ETm to be applied to the crop at each Ky stage and estimates the amount of irrigation water required to reach that level of deficit by using the TMY climatic data and the MOPECO simulation model (1st optimization). Thus, during the first Ky stage, the objective is to apply the irrigation schedule that reaches the ETa/ETm objective determined by the methodology for that stage under real management conditions. At the end of the first stage, the $\mathrm{ETa} / \mathrm{ETm}$ reached by the crop (estimated by MOPECO) should be similar to the target (in the first stage there is sufficient irrigation water) or higher (if the climatic conditions and/or the soil water availability do not allow that level of deficit to be generated). However, the amount of irrigation water applied to the crop will likely be different to that forecast by the model. Consequently, after the first Ky stage, the methodology determines new ETa/ETm targets for the following Ky stages, taking into account the actual remaining irrigation water (2nd optimization). The same methodology is followed at the end of each Ky stage. During the optimizations, a certain amount of irrigation water is saved for the last stage (that determined in the 2nd optimization) in order to avoid the total depletion of irrigation water during previous Ky stage. This methodology has been successfully applied under real management conditions in barley and garlic, as explained below.

\subsubsection{Applications}

In order to validate MOPECO and assess its applicability, the following experiments were conducted in commercial farms under different water availability scenarios [134,151-154].

The time and volume of water supplied to each experiment were determined by MOPECO and checked by soil moisture sensors or gravimetric samples.

Maize

The effect of irrigation uniformity on maize (Zea Mays L.) yield and profitability was evaluated in 2016 in Albacete (Spain), in two adjacent sectors equipped with a solid set sprinkler irrigation system [153]. The field was managed according to FAO-56 methodology throughout the growing season to maximize grain yield without water stress (Sector S1, considering 50\% adequacy) or irrigation scheduling determined by an experienced producer (Sector S2). Irrigation uniformity was evaluated using catch cans in both fields and grain yield was harvested within zones exhibiting $75 \%$ (Z1), 100\% (Z2), and $125 \%$ (Z3) of area-averaged volume applications throughout the year. The average coefficient of uniformity (CU) in both sectors (S1 and S2) was 83.5\%, and the net volume of applied irrigation water totalled $709 \mathrm{~mm}$ in S1 and $832 \mathrm{~mm}$ in S2. Irrigation Water productivity (WP) was higher in S1 $\left(2.20 \mathrm{~kg} \mathrm{~m}^{-3}\right)$ than in $\mathrm{S} 2\left(2.05 \mathrm{~kg} \mathrm{~m}^{-3}\right)$, highlighting the benefits of an accurate irrigation schedule on the efficient use of water. Nevertheless, average grain yield in sector $\mathrm{S} 2$ approached the maximum expected yield of $18.4 \mathrm{Mg} \mathrm{ha}^{-1}$ and exhibited no significant differences in yield among zones. In contrast, sector S1 exhibited significant yield differences $(\mathrm{p}<0.05)$ across zones with a measured yield in Z3 of $18.5 \mathrm{Mg} \mathrm{ha}^{-1}$ and a yield reduction of $1.6 \mathrm{Mg} \mathrm{ha}^{-1}$ and $4.0 \mathrm{Mg} \mathrm{ha}^{-1}$ in $\mathrm{Z} 2$ and Z1, respectively. Consequently, the area-averaged yield in $\mathrm{S} 1$ was $8 \%$ lower than in S2. This last treatment was positively influenced by a higher amount of irrigation water supplied to the crop $(17 \%)$, which decreased the effect of low CU (83.5\%). Because of these yield differences and the relatively low cost of irrigation water $\left(0.07 € \mathrm{~m}^{-3}\right)$, area averaged gross margin in S1 was $18 \%$ lower compared with S2, discouraging an efficient use of water by the farmer. On the other hand, the grain yields simulated by MOPECO for each monitoring zone within the sectors exhibited similar magnitude and trends. Simulations with MOPECO over a range of CU showed that improved irrigation uniformity increased area-averaged yields and gross margin when following the S1 instead of S2 strategy. In other words, efficient use of irrigation water through accurate irrigation scheduling and/or the use of regulated deficit irrigation techniques requires advanced management and maintenance of the irrigation systems. 
Purple garlic

A two years (2015-2016) “Morado de Las Pedroñeras" purple garlic field experiment was conducted in Albacete (Spain) [151]. The evaluated volumes of irrigation water were: no deficit "ND"; and four volumes of available irrigation water: 100\% "T100", $90 \%$ "T 90 ", $80 \%$ "T80", and 70\% "T70" of the net irrigation requirements $\left(\mathrm{In}=3400 \mathrm{~m}^{3} \mathrm{ha}^{-1}=\mathrm{T} 100\right)$ for the climatic conditions of the intermediate TMY). ORDI treatments reached high yields (between 10,055 kg ha-1 of treatment ND and $8260 \mathrm{~kg} \mathrm{ha}^{-1}$ of T70), also improving the productivity of the irrigation water (up to $7.7 \mathrm{~kg} \mathrm{~m}^{-3}$ with T70). Consequently, the blue water footprint (irrigation water) of purple garlic decreased from $0.287 \mathrm{~m}^{3} \mathrm{~kg}^{-1}$ of ND treatment to $0.173 \mathrm{~m}^{3} \mathrm{~kg}^{-1}$ of T70. The ND treatment achieved the best combination between yield and bulb calibre with high commercial value in both seasons. In 2015, the deficit treatments reached a similar distribution of calibres than that of the ND. However, the unfavourable climatic conditions of 2016 affected the distribution of calibres of ORDI treatments, shifting to calibres with lower price. Thus, the average profitability of the ND treatment was around $9800 € \mathrm{ha}^{-1} \mathrm{vs.} 6000 € \mathrm{ha}^{-1}$ of T70. Reaching the same total production of garlic in the productive area of purple garlic in CLM by using the T70 strategy instead of ND, it would be possible to reduce the irrigation requirements by around $37 \%$ with reductions in percolation due to better use of rainfall water. Nevertheless, the bulbs would be smaller, decreasing the price of the harvests and affecting the final profitability of the farms. This would be higher in wet years due to a larger area of the farm being cultivated with lower stressed garlic. In contrast, in dry years like 2016, profitability would decrease notably affecting the profitability of the farms. This may diminish the interest in this methodology in a highly profitable crop such as garlic, which requires high investment for its cultivation.

\section{Barley}

This experiment was similar to the previous one and was conducted during 2015, 2016 and 2017 seasons in Albacete (Spain) [154]. Five irrigation water volumes (one with no deficit "ND", and four limited volumes of available irrigation water, corresponding to $100 \%$ "T100", $90 \%$ "T 90 ", $80 \%$ "T 80 ", and $70 \%$ of IN $=2500 \mathrm{~m}^{3} \mathrm{ha}^{-1}$ ) were evaluated. As an average, ORDI achieved higher yields for the water received (between $9040 \mathrm{~kg} \mathrm{ha}^{-1}$ of the ND treatment and $6339 \mathrm{~kg} \mathrm{ha}^{-1}$ of the T70), enhancing irrigation water productivity (from $2.75 \mathrm{~kg} \mathrm{~m}^{-3}$ of the ND up to $3.64 \mathrm{~kg} \mathrm{~m}^{-3}$ of the T80). Accordingly, the barley blue water footprint was reduced, evolving from $0.360 \mathrm{~m}^{3} \mathrm{~kg}^{-1}$ of the ND to $0.275 \mathrm{~m}^{3} \mathrm{~kg}^{-1}$ of the T80. All the treatments fulfilled the quality requirements demanded by the malt industry, which were not affected by the ORDI strategy. As expected, the average profitability of ND treatment in the area (average $281.84 € \mathrm{ha}^{-1}$ ) was higher than the others (average $260.63 € \mathrm{ha}^{-1}$ for T80). Nevertheless, the application of the T80 methodology in all the barley area cultivated in the Eastern CLM region instead of ND during the three experimental years would involve a $30.1 \%$ reduction in irrigation water and a $13.3 \%$ increase in water productivity. This water saving $\left(38.3 \mathrm{hm}^{3}\right.$ in three years) could be used to replenish the Eastern CLM aquifer (at risk of over exploitation), reducing the pumping energy costs and improving the ecosystems depending on the aquifer, and/or to supply water to more profitable crops in the area improving the economy of the region.

\section{Barley, Maize and Onion}

This experiment was conducted in2014 and 2015 in Albacete (Spain) [134]. The objective was to compare the profitability of a 240 ha irrigated commercial farm considering two irrigation strategies. The traditional strategy $(\mathrm{T})$ consisted of applying full irrigation (F treatments) to a distribution of crops (barley, maize and onion), considering several volumes of irrigation water (from 2000 up to $8000 \mathrm{~m}^{3} \mathrm{ha}^{-1}$, varying the total area dedicated to each crop by using the direct solution algorithm obtained by MOPECO) and four market price scenarios considering a water cost of $0.12 € \mathrm{~m}^{-3}$. Depending on the availability of irrigation water, the MOPECO strategy $(\mathrm{M})$ consisted of applying to the same crops full irrigation or the combinations of water deficit per growing stage determined by ORDI 
methodology (O treatments). The optimal global deficits were: 30\% ETm for barley $(\mathrm{ETa} / \mathrm{ETm}=0.7), 10 \%$ $\mathrm{ETm}$ for maize $(\mathrm{ETa} / \mathrm{ETm}=0.9)$, and $10 \% \mathrm{ETm}$ for onion $(\mathrm{ETa} / \mathrm{ETm}=0.9)$. For low availabilities of irrigation water (between 2000 and $5000 \mathrm{~m}^{3} \mathrm{ha}^{-1}$ ), the M strategy achieved a profitability up to $8.2 \%$ higher than $T$ in the most favourable scenario, but the average for all the scenarios was around $2.8 \%$, which was much lower than expected $(8.0 \%)$ according to the simulations carried out by MOPECO using historic climatic and economic data. Despite the lower increase in profitability, in all the cases, the WP of the ORDI treatments was higher (average $12.4 \%$ for barley; $3.6 \%$ for maize; and $1.4 \%$ for onion). The causes of these results were the drought conditions of the two experimental years during spring time that increased the amount of water required by barley, the unfavourable climatic conditions during 2015 for onion and maize that decreased their yields and the price progression during both seasons (close to unprofitable values for onion in the first year). Thus, barley, a priori, the crop which could yield a water saving (because of its low profitability) required more water than forecast and decreased the availability of water for the other two crops. This work brought to light the necessity of modifying ORDI, resulting in the development of ORDI for limited volumes of water [138]. For higher availabilities of irrigation water (between 5000 and $8000 \mathrm{~m}^{3} \mathrm{ha}^{-1}$ ), the results of $\mathrm{F}$ and $\mathrm{O}$ scenarios were similar since there was sufficient water for avoiding deficit irrigation.

\section{Discussion}

The above study cases described the response of a wide range of crops to two different irrigation scheduling approaches under semi-arid conditions: one based on real time SWC measurements and the other based on simulation models.

The automatic irrigation system (AIS) efficiently processed and sent the user real-time field data (SWC, applied irrigation volume, and weather data). It also activated/deactivated the electrovalves that control the beginning and end of irrigation events. To this end, the AIS effectively combined the information collected by a wireless sensor (WS) network with climate information available through a web platform to actuate the electrovalves using ICT technologies. Likewise, all recorded data were stored in the cloud, being accessible anywhere/anytime for advisory services to farmers.

AIS can be adapted to different crops. In this work, it was implemented in woody crops (peach and nectarine). A deficit irrigation strategy was applied, achieving savings of around $30 \%$ in water, energy and labour costs compared to the conventional irrigation system.

It should be considered that the implementation of AIS in commercial farms involves the study of the spatial variability of the soil properties before the installation of the soil water sensors in order to select the monitoring point or points. A minimum of three probes is required to adequately represent the wet bulb. Hence, robust and cheap sensors for soil, plant, and atmosphere measurements are needed to promote the adoption of AIS in farms.

Regarding weather variables, real time and forecasted weather information provided by public and private weather services could be integrated in the irrigation schedule (rainfall time, intensity, ETo) to improve its accuracy $[155,156]$.

Sensor, hardware and software providers are currently involved in a process to enable the design of customized AIS based on SCADA or other middleware [155] to process inputs and operate irrigation networks in real time. Additionally, APPs implemented on hand-pocket smart devices will provide decision makers with an easy access to real-time data $[62,156]$.

Likewise, the WS networks, as well as the other technological components of AIS, require supervision and maintenance and a minimum level of knowledge for their handling and interpretation of the data. If the user does not have such knowledge, he/she should use technical advisory services.

The investment in the AIS (from $3000 €$, investment + operation) and the need for knowledge are the main limiting factor for commercial application of AIS. These deterrents have also been highlighted in other studies carried out in Australia, USA or European countries, such as Italy and Portugal [61,157-159]. In these analyses, authors state that farmers tend to maintain traditional agricultural practices and are usually reluctant to adopt new technologies [157]. In addition, the maintenance costs required is also 
a limiting factor for the incorporation of these new technologies [157]. Hence, knowledge exchange between researchers, farmers and other stakeholders is recommended to encourage the technological development and automation of irrigated agriculture [61].If this approach is properly transferred to the irrigation community, it will be a great step forward in the efficient use of water in irrigated agriculture. Thus, in regions with permanent water scarcity and high-value crops (e.g., Mediterranean environments), AIS can be worthwhile by underpinning highly profitable production with lower water endowments than traditional systems.

Furthermore, models like MOPECO are the core of decision support systems (DSS) that strengthen farmers' ability to preserve their profitability under low water availability conditions. MOPECO provides valuable information to improve crops distributions before planting and optimize irrigation scheduling in order to maximize water productivity. Additionally, at the level of water resource managers, it is also an adequate tool to analyse the effects of water policies on the agricultural sector.

MOPECO highlights the importance of suitable management of irrigation water through proper maintenance and use of the irrigation system, as well as determining the most suitable irrigation scheduling. In addition, under limited water availability conditions, MOPECO reduces water allocation for lower profitable crops (i.e., barley) and reallocates them to more profitable crops.

Farmers sometimes solve the lack of uniformity of their irrigation systems by supplying larger amounts of irrigation water than that required by crops. This strategy is evidently not justifiable from an environmental point of view, especially in areas where water is scarce. However, if water cost is low and/or the water authority does not offer any incentives to save water, farmers may use this strategy because it is easier than evaluating their irrigation system.

In addition to the lack of uniformity, irrigation schedules must be overestimated considering evaporation and drift losses in order to provide farmers with realistic values but avoiding percolation at least in mostof the field. These questions are even more significant when proposing farmers apply regulated deficit irrigation methodologies in annual crops.

MOPECO increases crop WP as a way to increase the profitability of farms by using the ORDI methodology. The drop in yield per unit of area is compensated for by a larger irrigated area with a higher WP, using the same amount of water within the farm. Consequently, ORDI does not decrease the amount of water used but increases the yield per unit of water volume supplied to the crop. This evidence has also been shown in previous works carried out in Australia, Spain, Morocco, and the Middle East. In these studies, adopting efficient irrigation systems has led to higher water use efficiencies but this water conservation has been used to expand the irrigated area or to change to more profitable crops [157-161].

Nevertheless, the effect of ORDI on the quality parameters of certain crops, such as horticultural ones, must be analysed before advising farmers to use it. Thus, in crops such as garlic or onion, ORDI increased WP but the decrease in the size of bulbs reduced their profitability per unit of yield, questioning the suitability of this methodology in this type of crops. Moreover, the increase in the cultivated area generates higher costs that must also be considered, although the cost per unit of area is lower (lower amount of water, fertilizers, harvest costs, etc.). Consequently, an economic analysis validated under real cropping conditions is required in these cases.

ORDI can be useful for farms where the amount of irrigation water is limited. The application of ORDI in garlic and barley under real management conditions showed an increase in WP, a reduced water footprint and a clear increase in the profitability of farms and barley cropping areas (and probably other cereals or low profitable crops). Transferring this methodology to the productive sector involves adapting these kinds of tools to the skills and necessities of farmers and technicians.

Applying models such as MOPECO requires calibration and validation processes before use, as well as the availability of local climatic data (public or private) and the installation of irrigation control devices (flow meters and soil moisture sensors), the number of which may vary depending on the total field area and its soil uniformity, using at least one monitoring point at two depths in the most representative area of the field i.e., at the location of the major roots depth concentration 
and at maximum root depth for controlling percolation. All these aspects entail costs for both the public administration and farmers themselves (individuals or associations), which maybe unaffordable for certain farms. Thus, in addition to developingthe tools and training the farmers and technicians, the total cost of the system is around $4650 €+$ taxes + installation.

Therefore, the positive results of the advanced technologies presented (AIS and DSS) are not without cost. They require investment in equipment, and expenditure on operation and maintenance, as well as qualified technical and maintenance services. Likewise, they need robust sensors, as well as the availability of advanced support services. In the case that such conditions are accomplished, these technologies will only be able to provide value to farms with low water availability, high profitability, and substantial technical-economic capacity.

Both irrigation programming approaches (AIS and DSS) are adequate tools to use irrigation water efficiently only if they are properly implemented in high uniformity irrigation networks. In irrigation systems with no accurate hydraulic design and poor maintenance (e.g., emitter clogging) water will never be used efficiently no matter how good the available irrigation management tools are.

\section{Conclusions}

This work reviews the main variables affecting optimal irrigation scheduling and their interrelationships. Two approaches to irrigation scheduling conducted in semi-arid areas of Southeast Spain are presented: one based on real time crop monitoring applied to woody crops at the farm scale and the other, for arable crops, applicable at the regional, irrigation district, and farm scales, based on water management models.

The analysis of both evaluated case studies shows that computer support and ICTs, availability of meteorological information and crop data during the growing season, sensors, and irrigation programmers among other elements are required to provide optimal irrigation scheduling solutions and improved resource allocation under water scarcity conditions. Additionally, to succeed in the adoption of these new water management technologies, well designed and maintained hydraulic facilities are needed. This implies investment and maintenance costs, which could make them unsuitable for low profitability farms.

In addition, adopting these approaches requires from the users technical training and willingness to accept irrigation schedules based not only on personal experience but also on data-driven decision-making processes. Hence, irrigation advisory services (public or private) can play a key role in driving this technology change in the irrigation sector. More robust and cheaper sensors would also contribute in this way.

Therefore, to date, the return of these technologies is worth the investments and costs required to use them in the case of farms with low water availability, high profitability, and relevant technical-economic capacity. Society, as an end beneficiary, may also play a key role in this technological change. The demand for sustainable crops is closely linked to optimal irrigation scheduling, which could raise the price of agricultural products and thus tip the balance in favour of the implementation of ICTs in irrigated agriculture.

Author Contributions: Conceptualization: P.M., I.F.G. and S.L.; methodology: P.M., I.F.G. and S.L.; investigation: P.M., I.F.G., S.L., M.C.R.-S., J.V., W.C., M.R.C., A.D., J.J.P. and B.C.L.; writing-original draft preparation: P.M., I.F.G., S.L., M.C.R.-S., J.V., W.C., M.R.C., A.D., J.J.P. and B.C.L.; writing-review and editing: P.M., I.F.G., S.L., M.C.R.-S., and A.D.; supervision: P.M., I.F.G. and S.L. All authors have read and agreed to the published version of the manuscript.

Funding: The methodologies and results showed in this paper were developed within the framework of several European (FLOW-AID "No. 036958 (GOCE)" and DeSURVEY "SUSTDEV-CT-2004-003950-2" funded by EC; and SUPROMED "GA-1813" funded by PRIMA) and Spanish Research Agency co-financed with European Union FEDER funds (AGL2014-59747-C2-1-R, AGL2016-77282-C3-1R and AGL2017-82927-C3-3-R) and Seneca Foundation of Region of Murcia (19903/GERM/15) projects. M.R. Conesa acknowledges the postdoctoral financial support received from Juan de la Cierva Spanish Program (FJCI-2017-32045).

Conflicts of Interest: The authors declare no conflict of interest. 


\section{References}

1. Food and Agriculture Organization of the United Nations. The Future of Food and Agriculture: Trends and Challenges; FAO: Rome, Italy, 2017; ISBN 9789251095515.

2. OECD. Innovation, Productivity and Sustainability in Food And Agriculture; Trade and Agriculture Directorate-Organisation for Economic Cooperation and Development: Paris, France, 2019.

3. English, M.J.; Solomon, K.H.; Hoffman, G.J. A paradigm shift in irrigation management. J. Irrig. Drain. Eng. 2002, 128, 267-277. [CrossRef]

4. Ruiz-Canales, A.; Ferrández-Villena, M. New proposals in the automation and remote control of water management in agriculture: Agromotic systems. Agric. Water Manag. 2015, 151, 1-3. [CrossRef]

5. Fernández, J. Plant-Based Methods for Irrigation Scheduling of Woody Crops. Horticulturae 2017, $3,35$. [CrossRef]

6. Gooley, L.; Huang, J.; Pagé, D.; Triantafilis, J. Digital soil mapping of available water content using proximal and remotely sensed data. Soil Use Manag. 2014, 30, 139-151. [CrossRef]

7. Maes, W.H.; Steppe, K. Perspectives for Remote Sensing with Unmanned Aerial Vehicles in Precision Agriculture. Trends Plant Sci. 2019, 24, 152-164. [CrossRef]

8. Neupane, J.; Guo, W. Agronomic Basis and Strategies for Precision Water Management: A Review. Agronomy 2019, 9, 87. [CrossRef]

9. McCarthy, A.C.; Hancock, N.H.; Raine, S.R. Advanced process control of irrigation: The current state and an analysis to aid future development. Irrig. Sci. 2013, 31, 183-192. [CrossRef]

10. Sadler, E.J.; Evans, R.G.; Stone, K.C.; Camp, C.R. Opportunities for conservation with precision irrigation. J. Soil Water Conserv. 2005, 60, 371-379.

11. Evans, R.G.; Sadler, E.J. Methods and technologies to improve efficiency of water use: Increasing water use efficiency. Water Resour. Res. 2008, 44. [CrossRef]

12. Gebbers, R.; Adamchuk, V.I. Precision Agriculture and Food Security. Science 2010, 327, 828-831. [CrossRef]

13. Balafoutis, A.; Beck, B.; Fountas, S.; Vangeyte, J.; Wal, T.; Soto, I.; Gómez-Barbero, M.; Barnes, A.; Eory, V. Precision Agriculture Technologies Positively Contributing to GHG Emissions Mitigation, Farm Productivity and Economics. Sustainability 2017, 9, 1339. [CrossRef]

14. Zarco-Tejada, P.J.; Hubbard, N.; Loudjani, P. Precision Agriculture: An opportunity for EU farmers-Potential support with the CAP 2014-2020. Jt. Res. Cent. Eur. Comm. Monit. Agric. Resour. Unit H04 2014.

15. FAO. Water for Sustainable Food and Agriculture. A Report Produced for the G20 Presidency of Germany; Food and Agriculture Organization of the United Nations: Rome, Italy, 2017.

16. NIFA-USDA Precision, Geospatial \& Sensor Technologies Programs. Available online: https://nifa.usda.gov/ program/precision-geospatial-sensor-technologies-programs\# (accessed on 9 March 2020).

17. Schimmelpfennig, D. Farm Profits and Adoption of Precision Agriculture; Economic Research Service-U.S. Department of Agriculture: Washington, DC, USA, 2016.

18. Barnes, A.P.; Soto, I.; Eory, V.; Beck, B.; Balafoutis, A.; Sánchez, B.; Vangeyte, J.; Fountas, S.; van der Wal, T.; Gómez-Barbero, M. Exploring the adoption of precision agricultural technologies: A cross regional study of EU farmers. Land Use Policy 2019, 80, 163-174. [CrossRef]

19. Watcharaanantapong, P.; Roberts, R.K.; Lambert, D.M.; Larson, J.A.; Velandia, M.; English, B.C.; Rejesus, R.M.; Wang, C. Timing of precision agriculture technology adoption in US cotton production. Precis. Agric. 2014, 15, 427-446. [CrossRef]

20. Barnes, A.; De Soto, I.; Eory, V.; Beck, B.; Balafoutis, A.; Sánchez, B.; Vangeyte, J.; Fountas, S.; van der Wal, T.; Gómez-Barbero, M. Influencing factors and incentives on the intention to adopt precision agricultural technologies within arable farming systems. Environ. Sci. Policy 2019, 93, 66-74. [CrossRef]

21. Galioto, F.; Raggi, M.; Viaggi, D. Assessing the Potential Economic Viability of Precision Irrigation: A Theoretical Analysis and Pilot Empirical Evaluation. Water 2017, 9, 990. [CrossRef]

22. Keisler, J.M.; Collier, Z.A.; Chu, E.; Sinatra, N.; Linkov, I. Value of information analysis: The state of application. Environ. Syst. Decis. 2014, 34, 3-23. [CrossRef]

23. Pierpaoli, E.; Carli, G.; Pignatti, E.; Canavari, M. Drivers of Precision Agriculture Technologies Adoption: A Literature Review. Procedia Technol. 2013, 8, 61-69. [CrossRef] 
24. Giannakis, E.; Bruggeman, A.; Djuma, H.; Kozyra, J.; Hammer, J. Water pricing and irrigation across Europe: Opportunities and constraints for adopting irrigation scheduling decision support systems. Water Sci. Technol. Water Supply 2016, 16, 245-252. [CrossRef]

25. Commission, E. Rural Development in the EU; Directorate-General for Agriculture and Rural Development-European Commission: Brussels, Belgium, 2013.

26. MAGRAMA. Aumenta La Superficie Regada en España Pero SE Mantiene Una Tendencia a La Baja en El Volume DE Agua DE Riego Utilizadoo en El Setor Agrario; Ministerio de Agricultura, Alimentación y Medio Ambiente: Madrid, España, 2015.

27. Salvador, R.; Martinez-Cob, A.; Cavero, J.; Playan, E. Seasonal on-farm irrigation performance in the Ebro basin (Spain): Crops and irrigation systems. Agric. Water Manag. 2011, 98, 577-587. [CrossRef]

28. Merchán, D.; Causapé, J.; Abrahão, R.; García-Garizábal, I. Assessment of a newly implemented irrigated area (Lerma Basin, Spain) over a 10-year period. I: Water balances and irrigation performance. Agric. Water Manag. 2015, 158, 277-287. [CrossRef]

29. Sánchez, J.A.; Reca, J.; Martínez, J. Irrigation Water Management in a Mediterranean Greenhouse District: Irrigation Adequacy Assessment. Irrig. Drain. 2015, 64, 299-313. [CrossRef]

30. Chalghaf, I.; Elhaddad, A.; García, L.A.; Lecina, S. Remote Sensing and District Database Programs for Irrigation Monitoring and Evaluation at a Regional Scale. J. Irrig. Drain. Eng. 2015, 141, 4015016. [CrossRef]

31. Malik, W.; Dechmi, F. DSSAT modelling for best irrigation management practices assessment under Mediterranean conditions. Agric. Water Manag. 2019, 216, 27-43. [CrossRef]

32. Tarjuelo, J.M.; Rodriguez-Diaz, J.A.; Abadía, R.; Camacho, E.; Rocamora, C.; Moreno, M.A. Efficient water and energy use in irrigation modernization: Lessons from Spanish case studies. Agric. Water Manag. 2015, 162, 67-77. [CrossRef]

33. Valdés-Vela, M.; Abrisqueta, I.; Conejero, W.; Vera, J.; Ruiz-Sánchez, M.C. Soft computing applied to stem water potential estimation: A fuzzy rule based approach. Comput. Electron. Agric. 2015, 115, 150-160. [CrossRef]

34. González Perea, R.; Camacho Poyato, E.; Montesinos, P.; Rodríguez Díaz, J.A. Optimization of Irrigation Scheduling Using Soil Water Balance and Genetic Algorithms. Water Resour. Manag. 2016, 30, 2815-2830. [CrossRef]

35. Lecina, S. Farmerless Profit-Oriented Irrigation Scheduling Strategy for Solid Sets. II: Assessment. J. Irrig. Drain. Eng. 2016, 142, 4015068. [CrossRef]

36. Lecina, S. Farmerless Profit-Oriented Irrigation Scheduling Strategy for Solid Sets. I: Development. J. Irrig. Drain. Eng. 2016, 142, 4015067. [CrossRef]

37. Harmanny, K.S.; Malek, Ž. Adaptations in irrigated agriculture in the Mediterranean region: An overview and spatial analysis of implemented strategies. Reg. Environ. Chang. 2019, 19, 1401-1416. [CrossRef]

38. Allen, R.G.; Pereira, L.; Raes, D.; Smith, M. Crop evapotranspiration: Guidelines for computing crop water requirements. In FAO Irrigation and Drainage Paper No. 56; FAO: Rome, Italy, 1998.

39. Allen, R. Using the FAO-56 dual crop coefficient method over an irrigated region as part of an evapotranspiration intercomparison study. J. Hydrol. 2000, 229, 27-41. [CrossRef]

40. Libardi, L.G.P.; de Faria, R.T.; Dalri, A.B.; de Souza Rolim, G.; Palaretti, L.F.; Coelho, A.P.; Martins, I.P. Evapotranspiration and crop coefficient $(\mathrm{Kc})$ of pre-sprouted sugarcane plantlets for greenhouse irrigation management. Agric. Water Manag. 2019, 212, 306-316. [CrossRef]

41. Wang, S.; Zhu, G.; Xia, D.; Ma, J.; Han, T.; Ma, T.; Zhang, K.; Shang, S. The characteristics of evapotranspiration and crop coefficients of an irrigated vineyard in arid Northwest China. Agric. Water Manag. 2019, 212, 388-398. [CrossRef]

42. Xu, G.; Xue, X.; Wang, P.; Yang, Z.; Yuan, W.; Liu, X.; Lou, C. A lysimeter study for the effects of different canopy sizes on evapotranspiration and crop coefficient of summer maize. Agric. Water Manag. 2018, 208, 1-6. [CrossRef]

43. Piccinni, G.; Ko, J.; Marek, T.; Howell, T. Determination of growth-stage-specific crop coefficients (KC) of maize and sorghum. Agric. Water Manag. 2009, 96, 1698-1704. [CrossRef]

44. Kumar, V.; Udeigwe, T.K.; Clawson, E.L.; Rohli, R.V.; Miller, D.K. Crop water use and stage-specific crop coefficients for irrigated cotton in the mid-south, United States. Agric. Water Manag. 2015, 156, 63-69. [CrossRef] 
45. Seidel, S.J.; Barfus, K.; Gaiser, T.; Nguyen, T.H.; Lazarovitch, N. The influence of climate variability, soil and sowing date on simulation-based crop coefficient curves and irrigation water demand. Agric. Water Manag. 2019, 221, 73-83. [CrossRef]

46. Ko, J.; Piccinni, G.; Marek, T.; Howell, T. Determination of growth-stage-specific crop coefficients (Kc) of cotton and wheat. Agric. Water Manag. 2009, 96, 1691-1697. [CrossRef]

47. Hargreaves, G.; Samani, Z. Reference Crop Evapotranspiration from Temperature. Appl. Eng. Agric. 1985, 1, 96-99. [CrossRef]

48. Spanish Ministry of Agriculture Fishing and Food Sistema de Información Agroclimática para el regadío (SiAR). Available online: http://eportal.mapama.gob.es/websiar/Inicio.aspx (accessed on 27 June 2019).

49. Yang, Y.; Cui, Y.; Luo, Y.; Lyu, X.; Traore, S.; Khan, S.; Wang, W. Short-term forecasting of daily reference evapotranspiration using the Penman-Monteith model and public weather forecasts. Agric. Water Manag. 2016, 177, 329-339. [CrossRef]

50. Mahmoud, S.H.; Gan, T.Y. Irrigation water management in arid regions of Middle East: Assessing spatio-temporal variation of actual evapotranspiration through remote sensing techniques and meteorological data. Agric. Water Manag. 2019, 212, 35-47. [CrossRef]

51. Traore, S.; Wang, Y.-M.; Kerh, T. Artificial neural network for modeling reference evapotranspiration complex process in Sudano-Sahelian zone. Agric. Water Manag. 2010, 97, 707-714. [CrossRef]

52. Xu, J.; Liu, X.; Yang, S.; Qi, Z.; Wang, Y. Modeling rice evapotranspiration under water-saving irrigation by calibrating canopy resistance model parameters in the Penman-Monteith equation. Agric. Water Manag. 2017, 182, 55-66. [CrossRef]

53. Cruz-Blanco, M.; Lorite, I.J.; Santos, C. An innovative remote sensing based reference evapotranspiration method to support irrigation water management under semi-arid conditions. Agric. Water Manag. 2014, 131, 135-145. [CrossRef]

54. NRCS. Irrigation Guide, National Engineering Handbook; Ross, A., Hardy, L.A., Eds.; USDA-NRCS: Washington, DC, USA, 1997.

55. Hengl, T.; De Jesus, J.M.; Heuvelink, G.B.M.; Gonzalez, M.R.; Kilibarda, M.; Blagotić, A.; Shangguan, W.; Wright, M.N.; Geng, X.; Bauer-Marschallinger, B.; et al. SoilGrids250m: Global gridded soil information based on machine learning. PLoS ONE 2017, 12, e0169748. [CrossRef]

56. Mubarak, I.; Mailhol, J.C.; Angulo-Jaramillo, R.; Ruelle, P.; Boivin, P.; Khaledian, M. Temporal variability in soil hydraulic properties under drip irrigation. Geoderma 2009, 150, 158-165. [CrossRef]

57. Yost, J.L.; Huang, J.; Hartemink, A.E. Spatial-temporal analysis of soil water storage and deep drainage under irrigated potatoes in the Central Sands of Wisconsin, USA. Agric. Water Manag. 2019, 217, $226-235$. [CrossRef]

58. García Morillo, J.; Rodríguez Díaz, J.A.; Camacho, E.; Montesinos, P. Drip Irrigation Scheduling Using Hydrus 2-D Numerical Model Application for Strawberry Production in South-West Spain. Irrig. Drain. 2017, 66, 797-807. [CrossRef]

59. Broner, I. Irrigation Scheduling. Fact Sheet No. 4708; Colorado State University Extension: Fort Collins, CO, USA, 2005.

60. Camp, C.R., Jr.; Sadler, E.J.; Evans, R.G. Precision Water Management: Current Realities, Possibilities and Trends. In Handbook of Precision Agriculture: Principles and Applications; Srinivasan, A., Ed.; Haworth Press: Binghamton, NY, USA, 2006; pp. 153-183.

61. Levidow, L.; Zaccaria, D.; Maia, R.; Vivas, E.; Todorovic, M.; Scardigno, A. Improving water-efficient irrigation: Prospects and difficulties of innovative practices. Agric. Water Manag. 2014, 146, 84-94. [CrossRef]

62. González Perea, R.; Fernández García, I.; Martin Arroyo, M.; Rodríguez Díaz, J.A.A.; Camacho Poyato, E.; Montesinos, P. Multiplatform application for precision irrigation scheduling in strawberries. Agric. Water Manag. 2017, 183, 194-201. [CrossRef]

63. González Perea, R.; Camacho Poyato, E.; Montesinos, P.; Rodríguez Díaz, J.A. Critical points: Interactions between on-farm irrigation systems and water distribution network. Irrig. Sci. 2014, 32, 255-265. [CrossRef]

64. Mérida García, A.; Fernández García, I.; Camacho Poyato, E.; Montesinos Barrios, P.; Rodríguez Díaz, J.A. Coupling irrigation scheduling with solar energy production in a smart irrigation management system. J. Clean. Prod. 2018, 175, 670-682. [CrossRef] 
65. Ramadan, K.M.; Oates, M.J.; Molina-Martinez, J.M.; Ruiz-Canales, A. Design and implementation of a low cost photovoltaic soil moisture monitoring station for irrigation scheduling with different frequency domain analysis probe structures. Comput. Electron. Agric. 2018, 148, 148-159. [CrossRef]

66. Soulis, K.X.; Elmaloglou, S. Optimum soil water content sensors placement for surface drip irrigation scheduling in layered soils. Comput. Electron. Agric. 2018, 152, 1-8. [CrossRef]

67. Miner, G.L.; Ham, J.M.; Kluitenberg, G.J. A heat-pulse method for measuring sap flow in corn and sunflower using 3D-printed sensor bodies and low-cost electronics. Agric. For. Meteorol. 2017, 246, 86-97. [CrossRef]

68. Corell, M.; Martín-Palomo, M.J.; Girón, I.; Andreu, L.; Trigo, E.; López-Moreno, Y.E.; Torrecillas, A.; Centeno, A.; Pérez-López, D.; Moriana, A. Approach using trunk growth rate data to identify water stress conditions in olive trees. Agric. Water Manag. 2019, 222, 12-20. [CrossRef]

69. Girona, J.; Mata, M.; Del Campo, J.; Arbonés, A.; Bartra, E.; Marsal, J. The use of midday leaf water potential for scheduling deficit irrigation in vineyards. Irrig. Sci. 2006, 24, 115-127. [CrossRef]

70. Martínez-Gimeno, M.A.; Castiella, M.; Rüger, S.; Intrigliolo, D.S.; Ballester, C. Evaluating the usefulness of continuous leaf turgor pressure measurements for the assessment of Persimmon tree water status. Irrig. Sci. 2017, 35, 159-167. [CrossRef]

71. Galindo, A.; Collado-González, J.; Griñán, I.; Corell, M.; Centeno, A.; Martín-Palomo, M.J.; Girón, I.F.; Rodríguez, P.; Cruz, Z.N.; Memmi, H.; et al. Deficit irrigation and emerging fruit crops as a strategy to save water in Mediterranean semiarid agrosystems. Agric. Water Manag. 2018, 202, 311-324. [CrossRef]

72. Navarro Navajas, J.M.; Montesinos, P.; Poyato, E.C.; Rodríguez Díaz, J.A. Impacts of irrigation network sectoring as an energy saving measure on olive grove production. J. Environ. Manag. 2012, 111, 1-9. [CrossRef]

73. Fernández García, I.; González Perea, R.; Moreno, M.A.; Montesinos, P.; Camacho Poyato, E.; Rodríguez Díaz, J.A. Semi-arranged demand as an energy saving measure for pressurized irrigation networks. Agric. Water Manag. 2017, 193, 22-29. [CrossRef]

74. UMass Center for Agriculture, F. and the E. Water: Supply and Sources. Available online: https://ag.umass.edu/ greenhouse-floriculture/greenhouse-best-management-practices-bmp-manual/water-supply-sources (accessed on 19 July 2019).

75. Garrido, A.; Martínez-Santos, P.; Llamas, M.R. Groundwater irrigation and its implications for water policy in semiarid countries: The Spanish experience. Hydrogeol. J. 2006, 14, 340-349. [CrossRef]

76. Ouyang, Y.; Feng, G.; Leininger, T.D.; Read, J.; Jenkins, J.N. Pond and Irrigation Model (PIM): A Tool for Simultaneously Evaluating Pond Water Availability and Crop Irrigation Demand. Water Resour. Manag. 2018, 32, 2969-2983. [CrossRef]

77. Alcalde-Sanz, L.; Gawlik, B.M. Minimum Quality Requirements for Water Reuse in Agricultural Irrigation and Aquifer Recharge-Towards a Legal Instrument on Water Reuse at EU Level; Publications Office of the European Union: Luxembourg, 2017.

78. California State Water Resources Control Board Water Rights FAQs. Available online: https://www. waterboards.ca.gov/waterrights/board_info/water_rights_process.html (accessed on 3 July 2019).

79. Knox, J.W.; Kay, M.G.; Weatherhead, E.K. Water regulation, crop production, and agricultural water management-Understanding farmer perspectives on irrigation efficiency. Agric. Water Manag. 2012, 108, 3-8. [CrossRef]

80. García Morillo, J.; Rodríguez-Díaz, J.A.; Camacho, E.; Montesinos, P. Linking water footprint accounting with irrigation management in high value crops. J. Clean. Prod. 2015, 87, 594-602. [CrossRef]

81. Morillo, J.G. Reducing Irrigation Inefficiencies in Water-Intensive Cropping: Evidence from Strawberry Production in South-West Spain. Outlook Agric. 2015, 44, 93-96. [CrossRef]

82. Li, M.; Xu, W.; Rosegrant, M.W. Irrigation, risk aversion, and water right priority under water supply uncertainty. Water Resour. Res. 2017, 53, 7885-7903. [CrossRef]

83. Nelson, K.S.; Burchfield, E.K. Effects of the Structure of Water Rights on Agricultural Production During Drought: A Spatiotemporal Analysis of California's Central Valley. Water Resour. Res. 2017, 53, 8293-8309. [CrossRef]

84. Berbel, J.; Esteban, E. Droughts as a catalyst for water policy change. Analysis of Spain, Australia (MDB), and California. Glob. Environ. Chang. 2019, 58, 101969. [CrossRef]

85. Rodríguez-Díaz, J.A.; Pérez-Urrestarazu, L.; Camacho-Poyato, E.; Montesinos, P. The paradox of irrigation scheme modernization: More efficient water use linked to higher energy demand. Spanish J. Agric. Res. 2011, 9, 1000-1008. [CrossRef] 
86. Hong, S.; Malaterre, P.-O.; Belaud, G.; Dejean, C. Optimization of water distribution for open-channel irrigation networks. J. Hydroinformatics 2014, 16, 341-353. [CrossRef]

87. Corominas, J. Agua y Energía en el riego en la época de la sostenibilidad. Ing. del Agua 2010, 17, $219-233$. [CrossRef]

88. Fernández García, I.; Creaco, E.; Rodríguez Díaz, J.A.; Montesinos, P.; Camacho Poyato, E.; Savic, D. Rehabilitating pressurized irrigation networks for an increased energy efficiency. Agric. Water Manag. 2016, 164, 212-222. [CrossRef]

89. Salvatierra-Bellido, B.; Montero-Martínez, J.; Pérez-Urrestarazu, L. Development of an automatic test bench to assess sprinkler irrigation uniformity in different wind conditions. Comput. Electron. Agric. 2018, 151, 31-40. [CrossRef]

90. Rodríguez-Díaz, J.A.; Perez Urrestarazu, L.; Camacho Poyato, E.; Montesinos, P. Modernizing water distribution networks: Lessons from the bembézar MD irrigation district, Spain. Outlook Agric. 2012, 41, 229-236. [CrossRef]

91. Carrillo, M.T.; Rodríguez-Díaz, J.A.; Montesinos, P.; López-Luque, R.L.; Camacho- Poyato, E.C. Low energy consumption seasonal calendar for sectoring operation in pressurized irrigation networks. Irrig. Sci. 2011, 29, 157-169. [CrossRef]

92. Fernández García, I.; Montesinos, P.; Camacho, E.; Rodríguez Díaz, J.A. Methodology for Detecting Critical Points in Pressurized Irrigation Networks with Multiple Water Supply Points. Water Resour. Manag. 2014, 28, 1095-1109. [CrossRef]

93. Fernández García, I.; Montesinos, P.; Camacho Poyato, E.; Rodríguez Díaz, J.A.A. Energy cost optimization in pressurized irrigation networks. Irrig. Sci. 2016, 34, 1-13. [CrossRef]

94. Casado, V. Estrategias del Uso del Agua y la Energía: Estudio de la Comunidad de Regantes de Fuente Palmera en la Campaña 2009-2010. Graduation Thesis, ETSIAM-Córdoba, Córdoba, Spain, 2012.

95. García Morillo, J.; McNabola, A.; Camacho, E.; Montesinos, P.; Rodríguez Díaz, J.A. Hydro-power energy recovery in pressurized irrigation networks: A case study of an Irrigation District in the South of Spain. Agric. Water Manag. 2018, 204, 17-27. [CrossRef]

96. Carrillo-Cobo, M.T.; Camacho-Poyato, E.; Montesinos, P.; Rodriguez-Diaz, J.A. Assessing the potential of solar energy in pressurized irrigation networks. The case of Bembézar MI irrigation district (Spain). Spanish J. Agric. Res. 2014, 12, 838-849. [CrossRef]

97. Migliaccio, K.W.; Morgan, K.T.; Vellidis, G.; Zotarelli, L.; Fraisse, C.; Zurweller, B.A.; Andreis, J.H.; Crane, J.H.; Rowland, D.L. Smartphone Apps for Irrigation Scheduling. Trans. Am. Soc. Agric. Biol. Eng. 2016, 59, $291-301$.

98. Nguyen, D.C.H.; Ascough, J.C.; Maier, H.R.; Dandy, G.C.; Andales, A.A. Optimization of irrigation scheduling using ant colony algorithms and an advanced cropping system model. Environ. Model. Softw. 2017, 97, 32-45. [CrossRef]

99. Chen, Y.; Marek, G.W.; Marek, T.H.; Brauer, D.K.; Srinivasan, R. Improving SWAT auto-irrigation functions for simulating agricultural irrigation management using long-term lysimeter field data. Environ. Model. Softw. 2018, 99, 25-38. [CrossRef]

100. Brown, P.D.; Cochrane, T.A.; Krom, T.D. Optimal on-farm irrigation scheduling with a seasonal water limit using simulated annealing. Agric. Water Manag. 2010, 97, 892-900. [CrossRef]

101. Linker, R.; Ioslovich, I.; Sylaios, G.; Plauborg, F.; Battilani, A. Optimal model-based deficit irrigation scheduling using AquaCrop: A simulation study with cotton, potato and tomato. Agric. Water Manag. 2016, 163, 236-243. [CrossRef]

102. Nasiakou, A.; Vavalis, M.; Zimeris, D. Smart energy for smart irrigation. Comput. Electron. Agric. 2016, 129, 74-83. [CrossRef]

103. Pulido-Calvo, I.; Montesinos, P.; Roldán, J.; Ruiz-Navarro, F. Linear regressions and neural approaches to water demand forecasting in irrigation districts with telemetry systems. Biosyst. Eng. 2007, 97, 283-293. [CrossRef]

104. Daccache, A.; Knox, J.W.; Weatherhead, E.K.; Daneshkhah, A.; Hess, T.M. Implementing precision irrigation in a humid climate-Recent experiences and on-going challenges. Agric. Water Manag. 2015, 147, 135-143. [CrossRef]

105. Piedelobo, L.; Ortega-Terol, D.; del Pozo, S.; Hernández-López, D.; Ballesteros, R.; Moreno, M.A.; Molina, J.L.; González-Aguilera, D. HidroMap: A new tool for irrigation monitoring and management using free satellite imagery. ISPRS Int. J. Geo-Inf. 2018, 7, 220. [CrossRef] 
106. González Perea, R.; Camacho Poyato, E.; Montesinos, P.; Rodríguez Díaz, J.A. Prediction of applied irrigation depths at farm level using artificial intelligence techniques. Agric. Water Manag. 2018, 206, 229-240. [CrossRef]

107. González Perea, R.; Camacho Poyato, E.; Montesinos, P.; Rodríguez Díaz, J.A. Optimisation of water demand forecasting by artificial intelligence with short data sets. Biosyst. Eng. 2019, 177, 59-66. [CrossRef]

108. González Perea, R.; Camacho Poyato, E.; Montesinos, P.; Rodríguez Díaz, J.A. Prediction of irrigation event occurrence at farm level using optimal decision trees. Comput. Electron. Agric. 2019, 157, 173-180. [CrossRef]

109. García Morillo, J.; Martín, M.; Camacho, E.; Rodríguez Díaz, J.A.; Montesinos, P. Toward precision irrigation for intensive strawberry cultivation. Agric. Water Manag. 2015, 151, 43-51. [CrossRef]

110. Hoekstra, A.Y.; Chapagain, A.K.; Aldaya, M.M.; Mekonnen, M.M. The Water Footprint Assessment Manual; Earthscan: London, UK, 2012; ISBN 9781849712798.

111. González Perea, R.; Camacho Poyato, E.; Montesinos, P.; García Morillo, J.; Rodríguez Díaz, J.A. Influence of spatio temporal scales in crop water footprinting and water use management: Evidences from sugar beet production in Northern Spain. J. Clean. Prod. 2016, 139, 1485-1495. [CrossRef]

112. Ruiz-Sanchez, M.C.; Domingo, R.; Castel, J.R. Review. Deficit irrigation in fruit trees and vines in Spain. Spanish J. Agric. Res. 2010, 8, 5-20. [CrossRef]

113. Vera, J.; Abrisqueta, I.; Conejero, W.; Ruiz-Sánchez, M.C. Precise sustainable irrigation: A review of soil-plant atmosphere Monitoring. Acta Hortic. 2017, 1150, 195-202. [CrossRef]

114. Mounzer, O.H.; Conejero, W.; Nicolás, E.; Abrisqueta, I.; García-Orellana, Y.V.; Tapia, L.M.; Vera, J.; Abrisqueta, J.M.; Ruiz-Sánchez, M.D.C. Growth pattern and phenological stages of early-maturing peach trees under a Mediterranean climate. HortScience 2008, 43, 1813-1818. [CrossRef]

115. Abrisqueta, I.; Abrisqueta, J.M.; Tapia, L.M.; Munguía, J.P.; Conejero, W.; Vera, J.; Ruiz-Sánchez, M.C. Basal crop coefficients for early-season peach trees. Agric. Water Manag. 2013, 121, 158-163. [CrossRef]

116. Abrisqueta,J.M.; Mounzer, O.; Álvarez, S.; Conejero, W.; García-Orellana, Y.; Tapia, L.M.; Vera, J.; Abrisqueta, I.; Ruiz-Sánchez, M.C. Root dynamics of peach trees submitted to partial rootzone drying and continuous deficit irrigation. Agric. Water Manag. 2008, 95, 959-967. [CrossRef]

117. Abrisqueta, I.; Tapia, L.M.; Conejero, W.; Sanchez-Toribio, M.I.; Abrisqueta, J.M.; Vera, J.; Ruiz-Sanchez, M.C. Response of early-peach [Prunus persica (L.)] trees to deficit irrigation. Spanish J. Agric. Res. 2010, 8, 30-39. [CrossRef]

118. Vera, J.; Padilla, A.M.; Ruiz-Sánchez, M.C.; Abrisqueta, I.; Tapia, L.M.; Munguía, J.P.; Abrisqueta, J.M. Automatic Drip Irrigation in Peach Trees Based on Soil Water Content Measured by FDR Probes. In Third International Symposium on Soil Water Measurement Using Capacitance, Impedance and Time Domain Transmission; Paltineanu Caton, I., Munoz Vera, J., Eds.; Paltin International Incorporated, 201: Murcia, Spain, 2010; ISBN1 0982796927. ISBN2 9780982796924.

119. Abrisqueta, I.; Vera, J.; Tapia, L.M.; Abrisqueta, J.M.; Ruiz-Sánchez, M.C. Soil water content criteria for peach trees water stress detection during the postharvest period. Agric. Water Manag. 2012, 104, 62-67. [CrossRef]

120. Vera, J.; Abrisqueta, I.; Abrisqueta, J.M.; Ruiz-Sánchez, M.C. Effect of deficit irrigation on early-maturing peach tree performance. Irrig. Sci. 2013, 31,747-757. [CrossRef]

121. Ruiz-Sánchez, M.C.; Abrisqueta, I.; Conejero, W.; Vera, J. Deficit irrigation management in early-maturing peach crop. In Water Scarcity and Sustainable Agriculture in Semiarid Environment: Tools, Strategies, and Challenges for Woody Crops; Elsevier BV: Amsterdam, The Netherlands, 2018; Volume 6, pp. 111-129.

122. Gardner, W.R. Dynamic aspects of water availability to plants. Soil Sci. 1960, 89, 63-73. [CrossRef]

123. Vera, J.; Conejero, W.; Conesa, M.R.; Ruiz-Sánchez, M.C. Irrigation factor approach based on soil water content: A nectarine orchard case study. Water 2019, 11, 589. [CrossRef]

124. Chalmers, D.J.; Mitchell, P.D.; Van Heek, L. Control of peach tree growth and productivity by regulated water supply, tree density, and summer pruning. Am. Soc. Hortic. Sci. 1981, 106, 307-312.

125. Steduto, P.; Hsiao, T.C.; Fereres, E.; Raes, D. Crop Yield Response to Water. FAO Irrigation and Drainage Paper 66; Food and Agriculture Organization of the United Nations: Rome, Italy, 2012; ISBN 978-92-5-107274-5.

126. De la Rosa, J.M.; Domingo, R.; Gómez-Montiel, J.; Pérez-Pastor, A. Implementing deficit irrigation scheduling through plant water stress indicators in early nectarine trees. Agric. Water Manag. 2015, 152, 207-216. [CrossRef]

127. Handley, D.F.; Johnson, R.S. Late summer irrigation of water-stressed peach trees reduces fruit doubles and deep sutures. HortScience 2000, 35, 771. [CrossRef] 
128. Pérez-Pastor, A.; Ruiz-Sánchez, M.C.; Conesa, M.R. Drought stress effect on woody tree yield. In Water Stress and Crop Plants: A Sustainable Approach; John Wiley \& Sons, Ltd.: London, UK, 2016; pp. 356-374. ISBN 9781119054450.

129. Paltineanu, I.C.; Starr, J.L. Real-time Soil Water Dynamics Using Multisensor Capacitance Probes: Laboratory Calibration. Soil Sci. Soc. Am. J. 1997, 61, 1576. [CrossRef]

130. Miller, G.A.; Farahani, H.J.; Hassell, R.L.; Khalilian, A.; Adelberg, J.W.; Wells, C.E. Field evaluation and performance of capacitance probes for automated drip irrigation of watermelons. Agric. Water Manag. 2014, 131, 124-134. [CrossRef]

131. Osroosh, Y.; Peters, R.T.; Campbell, C.S.; Zhang, Q. Comparison of irrigation automation algorithms for drip-irrigated apple trees. Comput. Electron. Agric. 2016, 128, 87-99. [CrossRef]

132. Spanish Ministry of Agriculture Fishing and Food Anuario de Estadística. Available online: https: //www.mapa.gob.es/es/estadistica/temas/publicaciones/anuario-de-estadistica/default.aspx (accessed on 17 December 2019).

133. Domínguez, A.; de Juan, J.A. Agricultural water management in Castilla-Lamancha (Spain). In Agricultural Water Management Research Trends; Sorensen, M.L., Ed.; Nova Science Publishers, Inc.: New York, NY, USA, 2008; pp. 69-128. ISBN 978-1-60456-159-3.

134. Domínguez, A.; Martínez-Navarro, A.; López-Mata, E.; Tarjuelo, J.M.; Martínez-Romero, A. Real farm management depending on the available volume of irrigation water (part I): Financial analysis. Agric. Water Manag. 2017, 192, 71-84. [CrossRef]

135. JCCM Pacto por la Recuperación Económica de Castilla-La Mancha 2015-2020|Gobierno de Castilla-La Mancha. Available online: https:/www.castillalamancha.es/gobierno/economiaempresasyempleo/estructura/ sgecoempreemple/actuaciones/pacto-por-la-recuperación-económica-de-castilla-la-mancha-2015-2020 (accessed on 17 December 2019).

136. López-Mata, E.; Orengo-Valverde, J.J.; Tarjuelo, J.M.; Martínez-Romero, A.; Domínguez, A. Development of a direct-solution algorithm for determining the optimal crop planning of farms using deficit irrigation. Agric. Water Manag. 2016, 171, 173-187. [CrossRef]

137. Domínguez, A.; Martínez, R.S.; De Juan, J.A.; Martínez-Romero, A.; Tarjuelo, J.M. Simulation of maize crop behavior under deficit irrigation using MOPECO model in a semi-arid environment. Agric. Water Manag. 2012, 107, 42-53. [CrossRef]

138. Leite, K.N.; Martínez-Romero, A.; Tarjuelo, J.M.; Domínguez, A. Distribution of limited irrigation water based on optimized regulated deficit irrigation and typical metheorological year concepts. Agric. Water Manag. 2015, 148, 164-176. [CrossRef]

139. Doorenbos, J.; Kassam, A.H.; Bentvelsen, C.; Uittenbogaard, G. Yield Response to Water. In Irrigation and Agricultural Development; Elsevier: Amsterdam, The Netherlands, 1980; pp. 257-280.

140. Carvalho, D.F.; Domínguez, A.; Neto, D.H.O.; Tarjuelo, J.M.; Martínez-Romero, A. Combination of sowing date with deficit irrigation for improving the profitability of carrot in a tropical environment (Brazil). Sci. Hortic. 2014, 179, 112-121. [CrossRef]

141. Domínguez, A.; Tarjuelo, J.M.; de Juan, J.A.; López-Mata, E.; Breidy, J.; Karam, F. Deficit irrigation under water stress and salinity conditions: The MOPECO-Salt Model. Agric. Water Manag. 2011, 98, 1451-1461. [CrossRef]

142. Domínguez, A.; de Juan, J.A.; Tarjuelo, J.M.; Martínez, R.S.; Martínez-Romero, A. Determination of optimal regulated deficit irrigation strategies for maize in a semi-arid environment. Agric. Water Manag. 2012, 110, 67-77. [CrossRef]

143. Domínguez, A.; Jiménez, M.; Tarjuelo, J.M.; de Juan, J.A.; Martínez-Romero, A.; Leite, K.N. Simulation of onion crop behavior under optimized regulated deficit irrigation using MOPECO model in a semi-arid environment. Agric. Water Manag. 2012, 113, 64-75. [CrossRef]

144. Domínguez, A.; Martínez-Romero, A.; Leite, K.N.; Tarjuelo, J.M.; de Juan, J.A.; López-Urrea, R. Combination of typical meteorological year with regulated deficit irrigation to improve the profitability of garlic growing in central spain. Agric. Water Manag. 2013, 130, 154-167. [CrossRef]

145. Leite, K.N.; Cabello, M.J.; Valnir Júnior, M.; Tarjuelo, J.M.; Domínguez, A. Modelling sustainable salt water management under deficit irrigation conditions for melon in Spain and Brazil. J. Sci. Food Agric. 2015, 95, 2307-2318. [CrossRef] 
146. López-Mata, E.; Tarjuelo, J.M.; de Juan, J.A.; Ballesteros, R.; Domínguez, A. Effect of irrigation uniformity on the profitability of crops. Agric. Water Manag. 2010, 98, 190-198. [CrossRef]

147. Stewart, J.I.; Hagan, R.M.; Pruitt, W.O.; Kanks, R.J.; Riley, J.P.; Danilson, R.E.; Franklin, W.T.; Jackson, E.B. Optimizing Crop Production Through Control of Water and Salinity Levels; PWRG 151-1; Utah Water Research Laboratory: Logan, UT, USA, 1977.

148. Hall, I.; Prairie, R.; Anderson, H.; Boes, E. Generation of typical meteorological years for 26 SOLMET stations; Sandia Lab. Rep. SAND 78-1601; Sandia National Laboratories: Albuquerque, NM, USA, 1979.

149. Márquez, A.L.; Baños, R.; Gil, C.; Montoya, M.G.; Manzano-Agugliaro, F.; Montoya, F.G. Multi-objective crop planning using pareto-based evolutionary algorithms. Agric. Econ. 2011, 42, 649-656. [CrossRef]

150. Sadras, V.; Calderini, D.; Fereres, E.; González-Dugo, V. Improving Productivity to Face Water Scarcity in Irrigated Agriculture. Crop Physiol. 2009, 122-143.

151. Lellis, B. Efecto del Riego Deficitario Controlado Optimizado por Etapas, para Volúmenes Limitados de Agua, en el Rendimiento y la Calidad del ajo Morado de Las Pedroñeras. Ph.D. Thesis, Universidad de Castilla-La Mancha, Ciudad Real, Spain, 2017.

152. Léllis, B.C.; Carvalho, D.F.; Martínez-Romero, A.; Tarjuelo, J.M.; Domínguez, A. Effective management of irrigation water for carrot under constant and optimized regulated deficit irrigation in Brazil. Agric. Water Manag. 2017, 192, 294-305. [CrossRef]

153. Nascimento, A.K.; Schwartz, R.C.; Lima, F.A.; López-Mata, E.; Domínguez, A.; Izquiel, A.; Tarjuelo, J.M.; Martínez-Romero, A. Effects of irrigation uniformity on yield response and production economics of maize in a semiarid zone. Agric. Water Manag. 2019, 211, 178-189. [CrossRef]

154. Pardo Descalzo, J.J. Efecto del Riego Deficitario Controlado Optimizado por Etapas, para Volúmenes Limitados de Agua, en el Rendimiento y la Calidad de la Cebada Cervecera. Ph.D. Thesis, Universidad de Castilla-La Mancha, Ciudad Real, Spain, 2019.

155. González Perea, R.; Mérida García, A.; Fernández García, I.; Camacho Poyato, E.; Montesinos, P.; Rodríguez Díaz, J.A. Middleware to Operate Smart Photovoltaic Irrigation Systems in Real Time. Water 2019, 11, 1508. [CrossRef]

156. Alcaide Zaragoza, C.; Fernández García, I.; González Perea, R.; Camacho Poyato, E.; Rodríguez Díaz, J.A. REUTIVAR: Model for Precision Fertigation Scheduling for Olive Orchards Using Reclaimed Water. Water 2019, 11, 2632. [CrossRef]

157. Schaible Glenn, D.; Aillery Marcel, P. Water Conservation in Irrigated Agriculture: Trends and Challenges in the Face of Emerging Demands. Available online: https://www.ers.usda.gov/publications/pub-details/ ?pubid=44699 (accessed on 13 February 2020).

158. Perry, C.; Steduto, P.; Karajeh, F. Does Improved Irrigation Technology Save Water? A Review of the Evidence. Discussion Paper on Irrigation and Sustainable Water Resources Management in the Near East and North Africa |Policy Support and Governance| Food and Agriculture Organization of the United Nations. Available online: http://www.fao.org/policy-support/resources/resources-details/en/c/897549/ (accessed on 13 February 2020).

159. Koech, R.; Langat, P. Improving Irrigation Water Use Efficiency: A Review of Advances, Challenges and Opportunities in the Australian Context. Water 2018, 10, 1771. [CrossRef]

160. Fernández García, I.; Rodríguez Díaz, J.A.; Camacho Poyato, E.; Montesinos, P.; Berbel, J. Effects of modernization and medium term perspectives on water and energy use in irrigation districts. Agric. Syst. 2014, 131, 56-63. [CrossRef]

161. Molle, F.; Tanouti, O. Squaring the circle: Agricultural intensification vs. water conservation in Morocco. Agric. Water Manag. 2017, 192, 170-179. [CrossRef]

(C) 2020 by the authors. Licensee MDPI, Basel, Switzerland. This article is an open access article distributed under the terms and conditions of the Creative Commons Attribution (CC BY) license (http://creativecommons.org/licenses/by/4.0/). 